\title{
Sm1, a Proteinaceous Elicitor Secreted by the Biocontrol Fungus Trichoderma virens Induces Plant Defense Responses and Systemic Resistance
}

\author{
Slavica Djonović, ${ }^{1}$ Maria J. Pozo, ${ }^{2}$ Lawrence J. Dangott, ${ }^{3}$ Charles R. Howell, ${ }^{4}$ and Charles M. Kenerley ${ }^{1}$ \\ ${ }^{1}$ Department of Plant Pathology and Microbiology, Texas A\&M University, College Station, TX 77843, U.S.A.; ${ }^{2}$ Department of \\ Soil Microbiology and Symbiotic Systems, Estación Experimental del Zaidín, CSIC, 18008 Granada, Spain; ${ }^{3}$ Department of \\ Biochemistry and Biophysics, Texas A\&M University, College Station; ${ }^{4}$ USDA-ARS Southern Plains Agricultural Research \\ Center, College Station, TX 77845, U.S.A.
}

Submitted 9 January 2006. Accepted 26 March 2006.

\begin{abstract}
The soilborne filamentous fungus Trichoderma virens is a biocontrol agent with a well-known ability to produce antibiotics, parasitize pathogenic fungi, and induce systemic resistance in plants. Even though a plant-mediated response has been confirmed as a component of bioprotection by Trichoderma spp., the molecular mechanisms involved remain largely unknown. Here, we report the identification, purification, and characterization of an elicitor secreted by T. virens, a small protein designated $\mathrm{Sm} 1$ (small protein 1). Sm1 lacks toxic activity against plants and microbes. Instead, native, purified Sm1 triggers production of reactive oxygen species in monocot and dicot seedlings, rice, and cotton, and induces the expression of defense-related genes both locally and systemically in cotton. Gene expression analysis revealed that $S M 1$ is expressed throughout fungal development under different nutrient conditions and in the presence of a host plant. Using an axenic hydroponic system, we show that $S M 1$ expression and secretion of the protein is significantly higher in the presence of the plant. Pretreatment of cotton cotyledons with $\mathrm{Sm} 1$ provided high levels of protection to the foliar pathogen Colletotrichum sp. These results indicate that $\mathrm{Sm} 1$ is involved in the induction of resistance by Trichoderma spp. through the activation of plant defense mechanisms.
\end{abstract}

Filamentous fungi from the genus Trichoderma have long been recognized as agents for the biocontrol of plant diseases. These free-living fungi are ubiquitous in the soil environment and are being successfully used and commercialized to combat a broad range of phytopathogenic fungi such as Rhizoctonia solani, Pythium ultimum, and Botrytis cinerea (Fravel 2005; Hjeljord et al. 2000). Trichoderma spp. can directly impact other fungi: after sensing a suitable fungal host, Trichoderma spp. respond with the production of antibiotic compounds, formation of specialized structures, and degradation of the host's cell wall, followed by the assimilation of its cellular content, a process known as mycoparasitism (Benitez et al. 2004; Chet and Chernin 2002). The mechanisms of mycoparasitism, antibiosis, and competition afforded by Trichoderma spp. have

Corresponding author: Charles M. Kenerley; Telephone: 979-845-8261; Fax: 979-845-6483; E-mail: c-kenerley@ tamu.edu

Nucleotide sequence for $S M 1$ is available in the GenBank database under accession number DQ121133. been widely studied (Harman et al. 2004a; Howell 2003). In fact, more than 100 different metabolites with known antimicrobial activities have been described so far, including antifungal cell-wall-degrading enzymes, peptaibols, and broad-spectrum antibiotics such as gliotoxin (Howell et al. 1993; Kim et al. 2002; Pozo at al. 2004; Sivasithamparam and Ghisalberti 1998; Wiest et al. 2002).

In addition to their mycoparasitic capabilities, many Trichoderma strains are "rhizosphere competent"; that is, they are able to colonize and grow in association with plant roots and significantly increase plant growth and development (Ahmad and Baker 1987). Cytological studies have demonstrated that Trichoderma hyphae are able to penetrate the root tissue and colonize several epidermal layers, but are restricted from spreading further by formation of plant cell wall appositions enriched with callose (Yedidia et al. 1999). Colonization by particular strains very rarely is detrimental to the plant or results in a pathogenic interaction (Harman et al. 2004a). In contrast, root colonization by Trichoderma spp. frequently is associated with induction of both local and systemic resistance to pathogen attack (Shoresh et al. 2005; Yedidia et al. 1999, 2000, 2003). Indeed, induction of systemic resistance against fungal and bacterial pathogens in diverse dicot and monocot plants has been demonstrated (Harman et al. 2004b; Howell et al. 2000; Yedidia et al. 2003). Even so, the relevance of the induction of plant resistance by Trichoderma spp. in the biocontrol process only recently has been envisaged (Harman et al. 2004a).

Extensive communication occurs between plants and microbes during the early stages of their association, in which signaling molecules play an essential role. Microbes are able to detect the plant host and initiate their colonization strategies, and plants are able to recognize microbe-derived molecules and tailor their defense responses according to the type of microorganism encountered. This molecular dialogue will determine the final outcome of the relationship, ranging from parasitism to mutualism, usually through highly coordinated cellular processes (Bais et al. 2004; Pozo et al. 2005). Signaling during plant-pathogen associations has been a central topic in phytopathology for many years, whereas more recent efforts are being made to understand the communication processes involved in plant interactions with nonpathogenic microorganisms, especially those improving plant fitness or inducing systemic resistance (Harrison 2005; Limpens and Bisseling, 2003; Pieterse et al. 1998). A large array of signaling molecules (elicitors) of microbial origin that initiate plant defense responses have been characterized (Nimchuk et al. 2003). Plant cells exposed to 
elicitors, whether crude fungal cell wall fragments or defined molecules such as purified proteins and avirulence gene products, respond with a battery of cellular changes related to defense (Hammond-Kosack and Jones 1996; Yang et al. 1997). These responses include rapid ion fluxes and the generation of reactive oxygen species, accumulation of phytoalexins, and synthesis of pathogenesis-related (PR) proteins such as chitinases and glucanases (Mittler et al. 2004; Nicholson and Hammershmidt 1992; Van Loon and Van Strien 1999). Small, cysteine-rich proteins are common among microbial molecules involved in early signaling, and include well-characterized types such as fungal avirulence gene products, elicitins, and hydrophobins (Templeton et al. 1994). Besides their involvement in pathogenicity (Tucker and Talbot 2001), some of these small proteins are proposed to play an important role in the specificity, recognition, and adhesion of symbiotic fungi to their host plants (Tagu et al. 2002; Wosten 2001).

During mycoparasitism, the ability of Trichoderma spp. to sense a potential fungal host has been demonstrated and regulatory sequences in the promoter region of mycoparasitismrelated genes and key elements in the signaling transduction pathways involved in regulation of these genes have been identified (Cortes et al. 1998; Mendoza-Mendoza et al. 2003; Zeilinger et al. 2005). However, a clear understanding of the Trichoderma spp.-plant recognition and communication process is lacking. Only proteins with enzymatic activity, such as cellulase and xylanase, have been described as proteinaceous elicitors in Trichoderma spp., because they induce a hypersensitive response, expression of PR proteins, and phytoalexins in different plant species (Calderon et al. 1993; Martinez et al. 2001; Ron et al. 2000). Evidence for the production of other metabolites by Trichoderma spp. involved in plant defense elicitation has been provided, but not fully characterized (Hanson and Howell 2004; Harman et al. 2004a).

In an attempt to bring new insights into the mechanisms underlying the processes of plant-Trichoderma spp. recognition, defense elicitation, and induction of resistance, we have identified, purified, and characterized a small protein secreted by Trichoderma virens, designated Sm1 (small protein 1). Using an axenic hydroponic system, we show that the presence of the plant enhances the expression of SM1. The protein belongs to a family of phytotoxic proteins, common among fungal pathogens. However, experiments with the native purified protein confirmed that Sm1 lacks toxic activity against plants and microbes; however, it is an effective elicitor able to trigger plant defense reactions both locally and systemically. The effectiveness of resistance induction was demonstrated against a foliar pathogen of cotton.

\section{RESULTS}

\section{Identification and isolation of Sm1 protein.}

Previous reports have indicated that $T$. virens induces defense responses in plants (Hanson and Howell 2004; Howell et al. 2000). With the aim of discovering elicitor molecules from this fungus, we analyzed the pattern of proteins secreted by the strain Gv29-8. Electrophoretic analysis of protein extracts from $T$. virens culture filtrates revealed a remarkable abundance of a low molecular weight protein found in many different nutritional conditions and developmental stages tested (data not shown). These characteristics, namely, consistent and high expression in media with varying substrates including plant roots, small size, and being secreted, are consistent with the characteristics of fungal elicitors or hydrophobins (Nimchuk et al. 2003; Templeton et al. 1994). The protein was isolated and subjected to N-terminal sequencing, and the 44-residue sequence DTVSYDTGYDNGSRSLNDVSCSDGPNGLETRYH
WSTQGQIPRFP was obtained. Similarity searches using MPsrch at the European Bioinformatics Institute revealed homology to elicitors and allergens from fungal pathogens of plants and humans. Therefore, the protein designated Sm1 appeared to be a good candidate as a signaling compound and deserved further study.

Cloning of the $S M 1$ gene and nucleotide sequence analysis.

Sequence similarity searches were performed (Blast) with the peptide sequence against the $T$. resee $i$ expressed sequence tag (EST) database and a matching EST was found. Specific primers were designed to amplify the corresponding gene. Polymerase chain reaction (PCR) amplification of T. virens genomic DNA using the designed SmF-SmR primer pair yielded a 264bp PCR product which was further sequenced. The deduced amino acid sequence of the PCR product was in agreement with the 44-residue sequence of Sm1 and the deduced amino acid sequence of $T$. resee $i$ EST. The labeled PCR product was used as a probe to isolate the SMI gene from the T. virens bacterial artificial chromosomal (BAC) library (Grzegorski 2001). A $3.5-\mathrm{kb}$ subclone containing SM1 was sequenced (GenBank accession number DQ121133). Southern analysis of T. virens Gv29-8 genomic DNA digested with restriction enzymes EcoRI, EcoRV, XbaI, BamHI, ApaI, and XhoI revealed that $S M 1$ is present as a single copy in the $T$. virens genome (data not shown).

The DNA sequence includes 261 bp of $5^{\prime}$ flanking region, an open reading frame (ORF) of $480 \mathrm{bp}$, and $259 \mathrm{bp}$ of $3^{\prime}$ flanking region (Fig. 1). The SMI ORF was interrupted by a single intron of $66 \mathrm{bp}$ at positions 62 to 127, as confirmed by comparative sequence analysis of genomic and cDNA. The SMI ORF encoded a polypeptide of 138 amino acids with a predicted molecular mass of $14,426.0 \mathrm{Da}$, an isoelectric point (pI) of 5.76, and a signal peptide of 18 amino acids. The $3^{\prime}$ region contained four putative polyadenylation signals (AAATA at 631, 653, and 663 and TAAATAA at 700) (Fig. 1). Analysis of the $5^{\prime}$ region of the SMI gene revealed putative TATA boxes at positions -28 and -171 and putative CAAT boxes at -81 and -104 upstream of the ATG codon. To study the presence of putative regulatory motifs in the promoter region of SM1 gene, the sequence analysis was expanded to $2 \mathrm{~kb}$ upstream of the ATG codon. Six CreA-binding motifs (5' SYGGRG 3') involved in catabolite repression in A. nidulans (Kulmburg et al. 1993; Sophianopoulou et al. 1993) were found at positions -1054 , $-1033,-1003,-948,-480$, and -403 . Only one HGATAR site, a possible binding consensus for nitrogen regulator such as AreA in A. nidulans (Ravagnani et al. 1997), was observed at position -1830 . Three GCCARG binding sites for PacC that mediates $\mathrm{pH}$ regulation in Aspergillus spp. (Tilburn et al. 1995) were found at $-1765,-1674$, and -816 . A stress response element (STRE), as described by Marchler and associates (1993) was located at -1600 . Only two of the four mycoparasitism response elements (MYREs) described in the promoter region of the mycoparasitism-related genes ech42 and prb1 of T. atroviride (Cortes et al. 1998), MYC1 (GCTTCA) and MYC3 (CGGCAC), were found at positions $-1925,-1669,-1218$, and -119 ; and -1104 and -623 ; respectively.

Analysis of the deduced amino acid sequence of Sm1 (Blastp) showed that Sm1 shares high similarity to proteins of several plant and human fungal pathogens (Fig. 2). The group includes several genes encoding for proteins known to be related to pathogenesis from phytopathogenic fungi: snodprotl gene of Phaeosphaeria nodorum (70\%), highly expressed during infection of wheat leaves (Hall et al. 1999); spl gene of Leptosphaeria maculans (69\%), expressed during the infection of Brassica napus cotyledons (Wilson et al. 2002); and cerato-platanin $(58 \%)$, a phytotoxic protein of the plane tree pathogen Cerato- 
cystis fimbriata f. sp. platani (Pazzagli et al. 1999). The highest similarity was to hypothetical proteins FG11205.1 of the cereal pathogen Gibberella zeae (77\%), 73\% to MG05344.4 of Magnaporthe grisea (rice blast fungus), and $71 \%$ to probable SnodProt1 PRECURSOR from the saprophytic fungus Neurospora crassa. Proteins homologous to Sm1 from human fungal pathogens include an allergen from Aspergillus fumigatus (67\%) (Hemmann et al. 1997) and an antigen (CS-Ag) with serine proteinase activity from Coccidioides immitis (67\%) (Pan and Cole 1995). Interestingly, a $70 \%$ similarity was found to an immunomodulatory protein (Aca1) from a medicinal fungus Antrodia camphorate (Hsu et al. 2005). Even though the amino acid sequence similarity between $\mathrm{Sm} 1$ and its homologues ranged from 58 to $77 \%$, the sequence alignment relies on the pattern of cysteine residues in the sequence (Fig. 2A). Searches against the Pfam protein families database (Bateman et al. 2004) for conserved domains at the National Center for Biotechnology Information server (Marchler-Bauer and Bryant 2004) show that residues 20 to 138 of the $S m 1$ protein align $99.2 \%(E$ value $=2 \mathrm{e}-43)$ over the length of the cerato-platanin family (pfam07249). This family contains a number of fungal cerato-platanin phytotoxic proteins approximately 150 residues long, containing four cysteine residues that form two disulphide bonds.

The amino acid composition of Sm1 reveals a high percentage of hydrophobic residues (40\%), including four cysteines and three tryptophans. The hydropathy plot generated from the Sm1-deduced sequence indicates that a putative cleavage site between the signal peptide and the mature, secreted protein is located between residues 18 and 19 (Fig. 2C). This prediction corresponds to the data obtained by $\mathrm{N}$-terminal sequencing of the secreted protein (Fig. 1, indicated by an arrow). Interestingly, the similarity of the amino acid sequence of signal peptides of Sm1 and its homologues is as high as 66\% (Fig. 2B). The mature Sm1 protein contains 120 amino acids, predicted molecular mass of $12,545.8 \mathrm{Da}$, and $\mathrm{pI}$ of 5.78. Motif analysis (ScanProsite) of the Sm1 deduced amino acid sequence identified several potential post-translational modifications: tyrosine sulfation site (residue 16), casein kinase II phosphorylation site (residue 25, 33, and 38), $N$-glycosylation site (residue 29), and $N$-myristoylation site (residue 65).

\section{Sm1 is expressed in all developmental stages \\ of the fungus and is induced in the presence of the plant.}

Northern analysis of SM1 transcript levels revealed basal levels of expression in all nutritional conditions tested (Fig. 3A). In the absence of a carbon source on Vogel's minimal medium (VM), relatively abundant $S M 1$ transcripts were detected at all time points. However, when Gv29-8 was growing in a medium with glucose as a carbon source (VMG), SM1 was repressed during the early time points. This early repression also was observed in a medium containing Rhizoctonia cell walls as a carbon source (VMR). In contrast to the upregulation observed in mycoparasitism related genes (Fig. 3A, middle panel) (Baek et al. 1999; Olmedo-Monfil et al. 2002; Pozo et al. 2004), expression of SMI in the presence of cell walls was observed only at later time points.

The second experiment examined SMI expression during different developmental stages of fungal growth (Fig. 3B). The

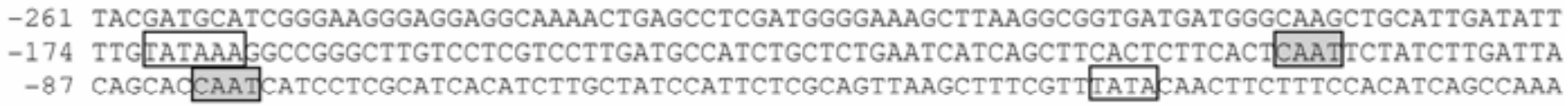

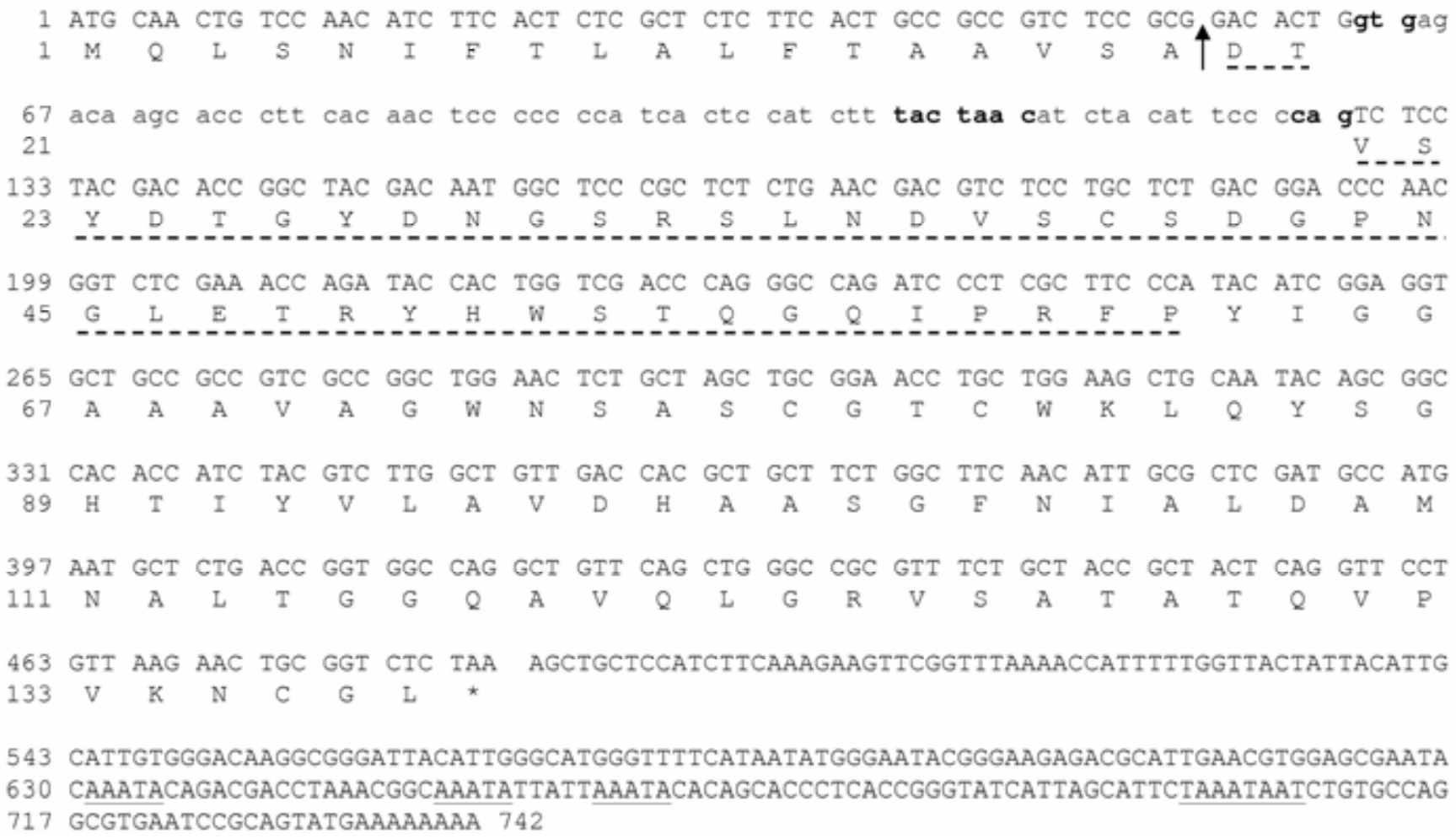

Fig. 1. Nucleotide and deduced amino acid sequences of Sm1. The predicted amino acid sequence of Sm1 is shown below the nucleotide sequence. The dashed underlined peptide sequence corresponds to that obtained by N-terminal sequencing of the protein. The SM1 open reading frame starts at position 1 and ends at 480. The intron sequence (at positions 62 to 127) is marked in lowercase. The consensus sequences for $5^{\prime}$ and $3^{\prime}$ intron splicing sites and for lariat formation are marked in bold. The arrow indicates the cleavage site of the signal peptide. The putative TATA and CAAT consensus sequences are in clear and shaded boxes, respectively. Solid underlined nucleotide sequences in the $3^{\prime}$ region represent putative polyadenylation signal sites. 
gene was expressed at all stages and under all conditions tested. $S M 1$ was expressed in germinating spores, with higher levels of transcription in spores germinating on a complex medium, potato dextrose agar (PDA), than on a minimal medium (VMS). As described for other fungi, germination occurs earlier on complex than on minimal media (data not shown), and that could account for the higher transcription levels on PDA at this stage. In both sporulating and nonsporulating (growing) mycelia, SM1 was expressed to a higher level in the defined medium (VMS) than in a complex one (PDA), coherently with the catabolic repression observed in the previous experiment. $S M 1$ also was found to be expressed during indirect confrontation with Rhizoctonia solani. Fungus grown in VMS liquid medium as submerged mycelia was used as positive control, because Sm1 protein isolated from culture filtrates showed maximum levels of expression under this condition.
A

TVSm1

GPSNODPROT-FS

PASNODPROT1

LmSp1

AcAcal

CiCs-ag

AfrAspf 13

CfCerato-platanin

TVSm1

GPSNODPROT-FS

PASNODPROT1

LmSp1

AcAca 1

CiCs-ag

AfrAspf13

CfCerato-platanin

TVSm1

GPSNODPROT-FS

PASNODPROT1

LmSp1

AcAca 1

CiCs-ag

AfrAspf 13

CfCerato-platanin

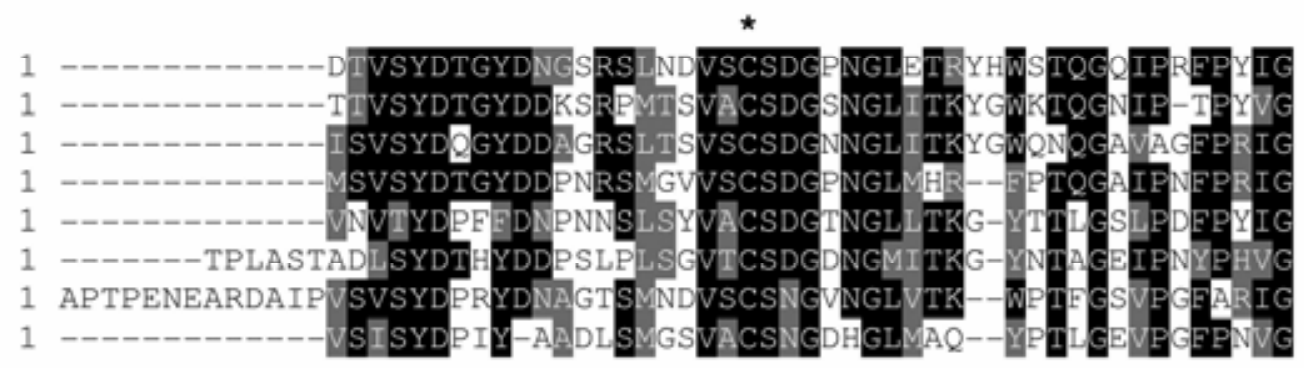

* $\quad$ *
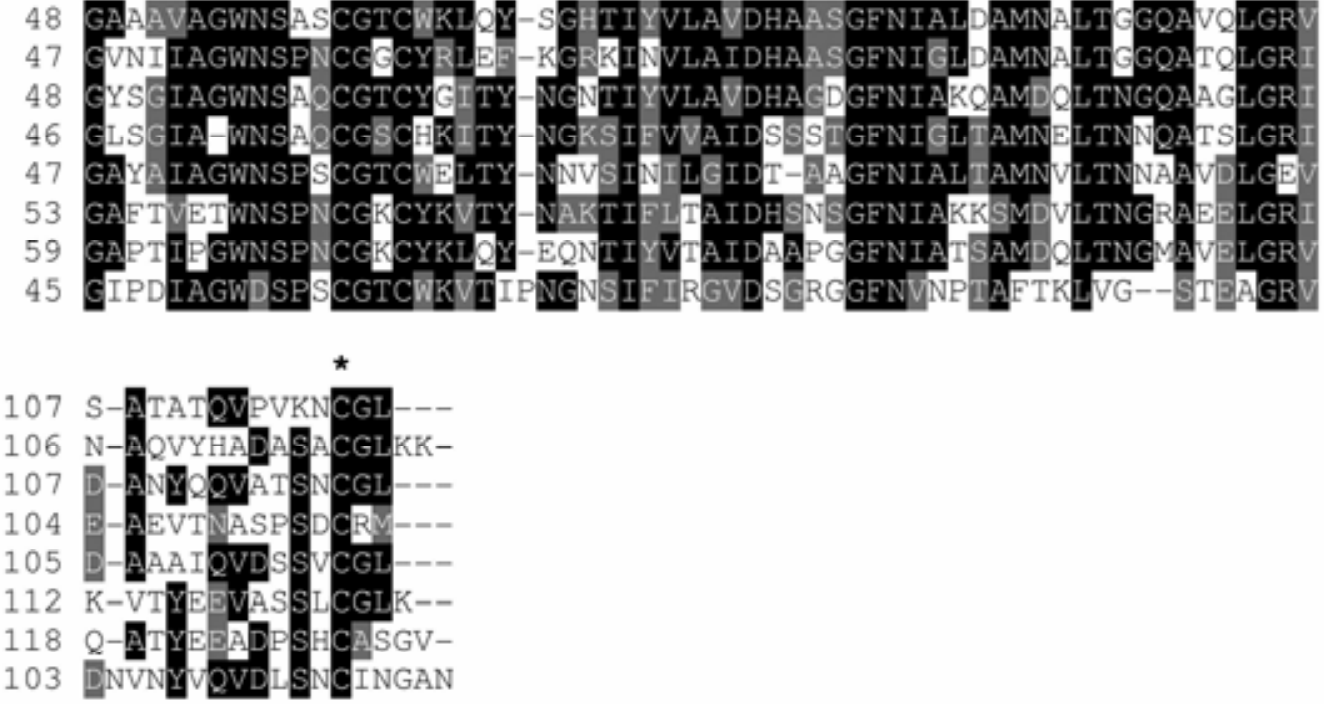

B

TVSm1
FS11205.1
NCSnodProt 1
MG05344. 4
GPSNODPROT-FS
ACACa1
PnSNODPROT1
LmSp1
CiCs-ag
CfCerato-platanin
AfrAspf13

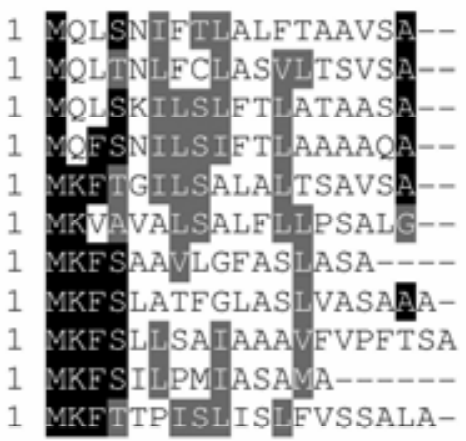

\section{C}

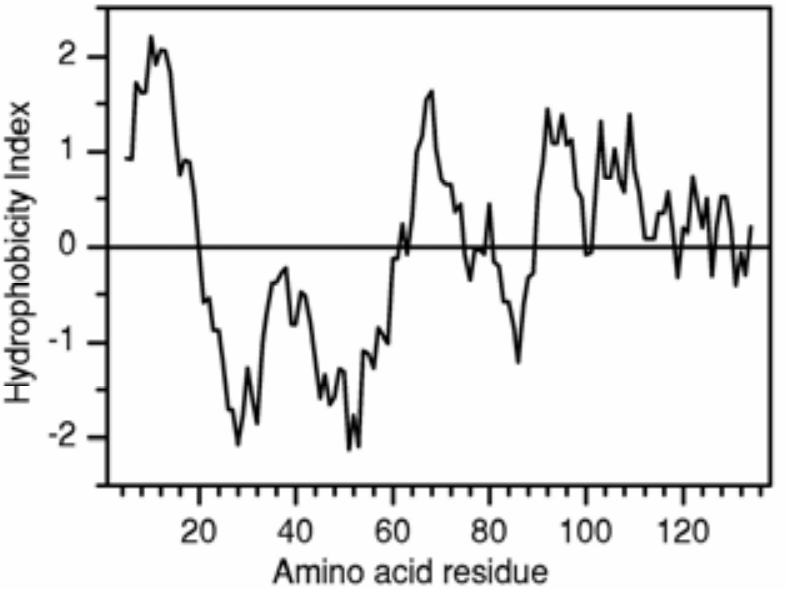

Fig. 2. Sequence alignments of $\mathbf{A}$, the amino acid sequences of Trichoderma virens $\mathrm{Sm} 1$ mature protein, $\mathbf{B}$, the signal peptide sequences and its homologues, and C, hydropathy plot of Sm1. Homologues: GpSNODPROT-FS (G. pulicaris), PnSNODPROT1 (Phaeosphaeria nodorum), LmSP1 (Leptosphaeria maculans), AcAca1 (Antrodia camphorate), CiCS-AG, (Coccidioides immitis), AfrAspf13 (Aspergillus fumigatus), CfCerato-platanin (Ceratocystis fimbriata f. sp. platani), FG11205.1 (Gibberella zeae PH-1), MG05344.4 (Magnaporthe grisea), and NCsnodprot1 (Neurospora crassa). GenBank accession numbers for the sequences are as follows: AY826795, AF074941, AY099225, AY569691, Q00398, AJ002026, AJ311644, AACM01000460, AACU01000497, and AL513410, respectively. Asterisks indicate the conserved cysteine residues. Identical amino acid residues are shaded in black and similar residues are shaded in gray. The hydropathic profile was calculated by the method of Kyte and Doolittle (1982) with a window of nine amino acids. 
Finally, we examined whether SMI gene expression was regulated by the presence of the plant using a hydroponic growth system that allowed the coculture of $T$. virens and cotton seedlings (Fig. 4A). RNA samples from $T$. virens growing in the hydroponic system with or without the seedlings were compared. SM1 transcript levels were higher when T. virens was growing in contact with the plant than when growing alone (Fig. 4B). In agreement, the analysis of the secreted proteins in the medium showed that $\mathrm{Sm} 1$ was more abundant in the filtrate from the plant-fungus coculture than in the filtrate from the fungus growing alone (Fig. 4C).

\section{Sm1 purification and matrix-assisted}

laser desorption ionization time-of-flight analysis.

To characterize the function of Sm1, we proceeded to purify $\mathrm{Sm} 1$ in its native form from $T$. virens Gv29-8 culture filtrates. Several purification steps were required beginning with the protein extracts being subjected to anion exchange chromatography (AEX). The AEX elution profile is shown in Figure 5A. $\mathrm{Sm} 1$ was eluted at approximately $80 \mathrm{mM} \mathrm{NaCl}$ (fraction 5, under the major peak). The AEX fraction containing Sm1 was further submitted to gel filtration chromatography (GFC) and pure $\mathrm{Sm} 1$ was eluted in fractions 48 to 55 (the major peak) (Fig. 5B). The successive purification step performed with GFC allowed isolation of a protein purified to homogeneity as demonstrated by sodium dodecyl sulfate polyacrylamide gel electrophoresis (SDS-PAGE) (Fig. 5C). Concentration of pure Sm1 protein was determined based on molar absorption coefficient (Pace et. al. 1995). The final yield of protein obtained from 1 liter of starting culture filtrate was approximately $1.6 \mathrm{mg}$.

The mass spectrum obtained by a matrix-assisted laser desorption ionization time-of-flight (MALDI/TOF) spectrometer of the pure native $\mathrm{Sm} 1$ protein revealed a single peak at $12,611.79 \mathrm{~m} / \mathrm{z}$ (data not shown). This mass determination is in
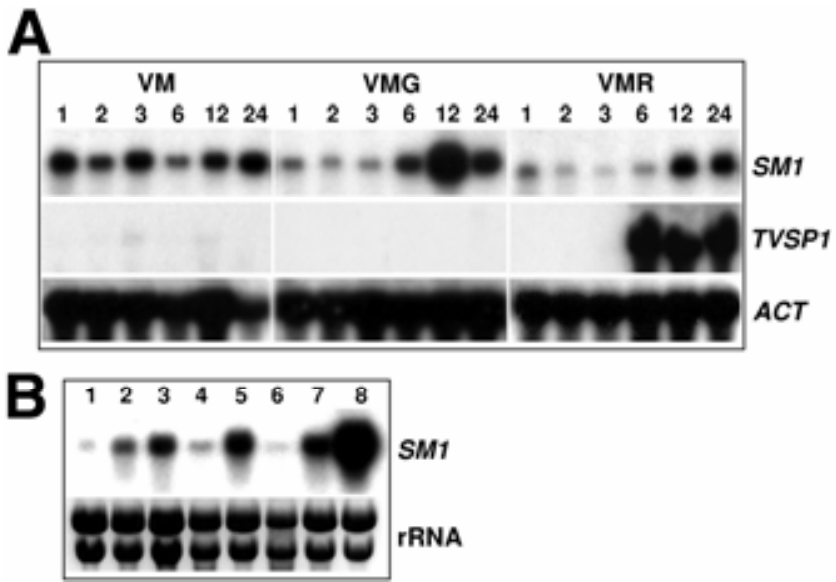

Fig. 3. Northern analysis of $S M 1$ expression. A, SM1 expression during growth of Trichoderma virens Gv29-8 in submerged culture under different nutritional conditions (Vogel's minimal medium without carbon source [VM] or supplemented with either $1.5 \%$ glucose [VMG] or $0.5 \%$ fungal cell walls from Rhizoctonia solani [VMR]). Expression of TVSP1 (Pozo et al. 2004) under the same conditions was included as a mycoparasitismrelated gene for comparison. B, $S M 1$ expression during different developmental stages of fungal growth: T. virens Gv29-8 spores germinating for $12 \mathrm{~h}$ on solid VMS (lane 1) or potato dextrose agar (PDA) medium (lane 2); 2-day-old nonsporulating mycelia cultured on solid VMS (lane 3) or PDA (lane 4); 5-day-old sporulating mycelia cultured on solid VMS (lane 5 ) or PDA (lane 6); T. virens mycelia indirectly confronted with $R$. solani (lane 7); 5-day-old VMS liquid culture of Gv29-8 (lane 8). Total RNA was extracted from indicated conditions and $15 \mu \mathrm{g}$ loaded per lane. Equal sample loading was confirmed by A, hybridizing the blot with ${ }^{32} \mathrm{P}-\mathrm{dCTP}$-labeled actin probe or by $\mathbf{B}$, ethidium bromide-staining of the rRNA in the gel. agreement with the predicted molecular weight of the mature protein according to the deduced amino acid sequence, suggesting that no post-translational modifications occur.

\section{Enzymatic and toxic activity tests.}

The properties of Sm1 were defined by conducting different activity tests with the purified protein. First, putative toxic activity against bacteria and fungi was tested. Sm1 was not found to inhibit the growth of any pathogenic bacteria, fungi, or oomycetes tested (Clavibacter michiganensis, Bacillus cereus, Xanthomonas campestris, and Agrobacterium tumefaciens; Mucor hiemalis, Sclerotium rolfsii, Botrytis cinerea, Fusarium oxysporum, Rhizoctonia solani, and Cochliobolus heterostrophus; and Pythium ultimum and Phytophthora infestans, respectively) in either dual culture or antibiotic disk assays, even when the highest dose was applied $(10 \mathrm{nmol})$. Additionally, the application of Sm1 did not result in any significant phytotoxicity against cotton, tobacco, peanut, or rice leaves because evidence of necrosis was not observed even though the leaves were wounded by needle to provide access to the mesophyll cells. Putative enzymatic activity of the pure protein for protease, chitinase, $\beta$-1,3-glucanase, and $\beta$-1,6-glucanase were not detected when Hide Azure powder, chymotrypsin substrate, 4methylumbelliferyl- $\beta$-D- $N, N^{\prime}, N$-triacetylchitotriose or 4-methylumbelliferyl- $\beta$-D-glucosaminide, laminarin, and pustulan were used as substrates, respectively (data not shown).

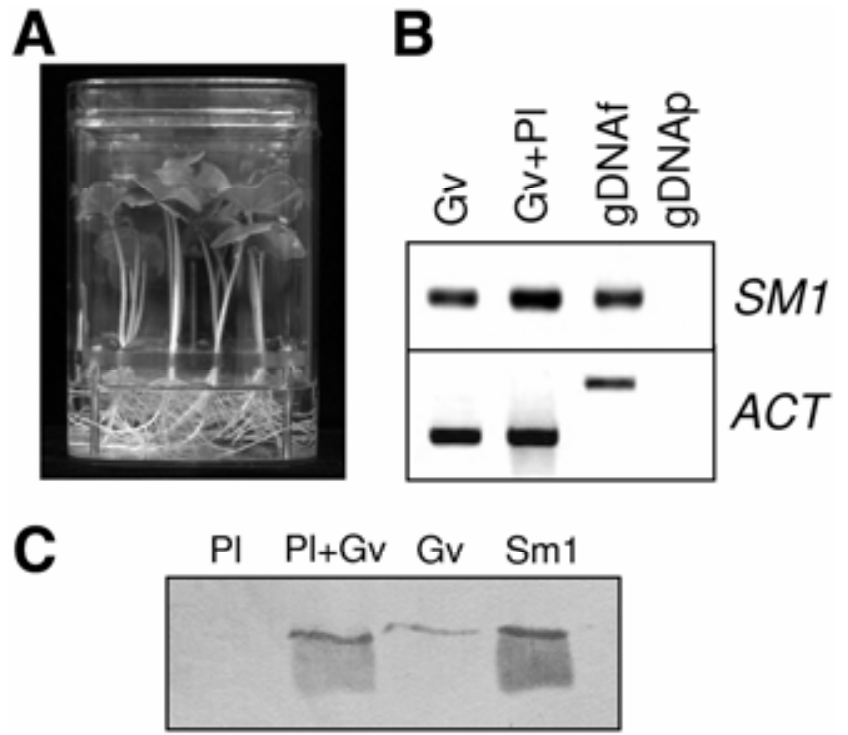

Fig. 4. Expression analysis of Trichoderma virens SM1 in the presence of a host plant. A, Experimental design for the hydroponic system for plantfungus coculture. Six-day-old cotton seedlings (Gossypium hirsutum cv. Paymaster 2326 BG/RR) were grown aseptically in Murashige and Skoog (MS) medium $(300 \mathrm{ml})$ in Lifeguard culture boxes. Then, the boxes were inoculated with a fungal preparation of $T$. virens Gv29.8 and incubated for $48 \mathrm{~h}(\mathrm{Gv}+\mathrm{Pl})$. Two more treatments were included: $T$. virens growing in MS in the absence of cotton seedlings $(\mathrm{Gv})$ and control plants growing in MS without $T$. virens $(\mathrm{Pl})$. B, Semiquantitative reverse-transcriptase polymerase chain reaction (sqRT-PCR) analysis of $S M 1$ expression in fungus growing in presence $(\mathrm{Gv}+\mathrm{Pl})$ or absence $(\mathrm{Gv})$ of the host. T. virens genomic DNA (gDNAf) was used as a positive control for the sqRT-PCR, and cotton genomic DNA was included to confirm the specificity of the primers to $T$. virens (gDNAp). Top panel, amplified SM1 products after sqRT-PCR using $S M 1$ specific primers. Bottom panel, amplification of the constitutively expressed actin gene for control of equal cDNA amounts. C, Immunoblot analyses for detection of Sm1 secreted in the hydroponic growth medium. Equal volumes of concentrated samples equivalent to $300 \mathrm{ml}$ of medium from the hydroponic system ( $\mathrm{Pl}, \mathrm{Gv}+\mathrm{Pl}$, and $\mathrm{Gv}$ ) were loaded on a $15 \%$ sodium dodecyl sulfate polyacrylamide electrophoresis gel and electroblotted to a nitrocellulose membrane. Pure Sm1 was included as positive control (Sm1). The polyclonal antibody raised against Sm1 was used. 
Sm1 induces early plant defense reactions in cotton and rice.

The lack of direct phytotoxic activity suggested a possible role of Sm1 as an elicitor of plant defense reactions. The production of reactive oxygen species (e.g., hydrogen peroxide) and accumulation of phenolic compounds (usually associated with autofluorescence of these compounds) are the early responses in plant-pathogen or elicitor recognition (Dixon et al. 1994; Hammond-Kosack and Jones 1996; Hutcheson 1998); therefore, we tested the ability of Sm1 to elicit these responses. The production of hydrogen peroxide in rice leaves (monocot) and cotton cotyledons (dicot) after exposure to Sm1 was examined. Application of a small amount of Sm1 $(1 \mathrm{nmol})$ resulted in the production of hydrogen peroxide in both plants. This reaction is illustrated by the appearance of a brownish-red precipitate in the treated tissues, generated by polymerization of the hydrogen peroxide with nitro 3,3'-diaminobenzidine (Fig. 6). The induction of autofluorescence was tested in cotton cotyledons. A very slight response was found in water-treated leaves, probably due to the wounding of the leaf during the treatment application. In contrast, high levels of autofluorescence are apparent after treatment with $1 \mathrm{nmol}$ of $\mathrm{Sm} 1$ or $52 \mathrm{nmol}$ of 2,6-dichloroisonicotinic acid (INA), a salicylic acid (SA) analog used as positive control (Fig. 7).

\section{Sm1 induces the expression}

of plant defense genes locally and systemically.

To gain further insight into the plant response to the Sm1 elicitor, and to determine if the induction is local (at the site of application) or systemic, several experiments were performed. The expression profile of defense-related genes in different cotton genotypes was determined by semiquantitative reversetranscriptase (RT)-PCR, using gene-specific primers (Table 1) and a Gossypium hirsutum actin gene $(A C T)$ as an internal control. For each gene, PCR was performed within the linear amplification range. Six genes related to different plant defense pathways were selected: $G L U$ and $C H T$ (PR proteins), $C A D 1-$ $C$ and $H M G$ (terpenoid phytoalexin pathway), and POD6 and GhLOX1 (related to oxidative burst and hypersensitive reactions) (Chen et al. 1995; Delannoy et al. 2003; Dowd et al. 2004; Jalloul et al. 2002). SA or INA was used as a positive control because both are known to resemble defense-related signal compounds for systemic acquired resistance to pathogen infection (Ward et al. 1991).
The expression of these defense-related genes first was examined locally at the site of application. Gene expression 12 $\mathrm{h}$ after application of $\mathrm{Sm} 1, \mathrm{SA}$, or $\mathrm{H}_{2} \mathrm{O}$ to cotton roots is shown in Figure 8A. Based on mRNA accumulation profiles, the expression of PR genes ( $G L U$ and $C H T$ ) was induced by Sm1 application in all three genotypes. Interestingly, treatment with SA did not yield such an induction of $G L U$ and CHT transcripts in Deltapine-50 or CA3274. Sm1 treatment also induced POD6 and LOX1 expression in all genotypes. Although LOX1 was induced by SA treatment, POD6 was not. $C A D 1-C$ and $H M G$ were constitutively expressed in the roots and showed no response to the $\mathrm{Sm} 1, \mathrm{SA}$, or $\mathrm{H}_{2} \mathrm{O}$ treatment. The effect on gene expression was similar when a much lower concentration of Sm1 (0.6 nmol/root) was applied (Fig. 8A, lane $\mathrm{Sm}^{\mathrm{a}}{ }^{\mathrm{a}}$ ). When $\mathrm{Sm} 1$ was applied to cotton cotyledons, local induction of defense genes was similar to the response observed in roots (Fig. 8B), except that $C A D 1-C$, which was constitutively expressed in roots, showed induction by Sm1 and INA treatments in the cotyledon tissue. A similar pattern was observed for $H M G$, a gene involved in the same pathway, although constitutive expression was notably higher. Sm1 elicitation caused a stronger upregulation of CAD1-C, $H M G, L O X 1$, and POD6 than treatment with INA. In summary, the treatment of plant roots or cotyledons with pure native Sm1 protein resulted in local induction of defenserelated genes in all three cotton genotypes tested, despite the low doses of Sm1 applied.

The possible induction of systemic defense reactions was analyzed in a system in which cotton roots (Deltapine-50) were exposed to Sm1 but contact of the protein with the leaves was avoided (Fig. 9A). Treatment with SA also was included as positive control. Gene expression was analyzed in the cotyledons after application of the treatments to the roots, and a clear systemic response was observed $24 \mathrm{~h}$ after application of Sm1 or SA (Fig. 9B). Similar to the local response observed in the treated tissues (roots and cotyledons), PR genes $G L U$ and $C H T$ were upregulated. Induction of $L O X 1$ and POD6 by both treatments also was observed. Both $C A D 1-C$ and $H M G$ were induced upon $\mathrm{Sm} 1$ treatment but not by SA. The gene expression profile of directly inoculated roots (data not shown) was similar to the pattern corresponding to roots sprayed with Sm1 and SA (Fig. 8A). These data indicated that Sm1 activated systemic expression of defense-related genes in cotton.
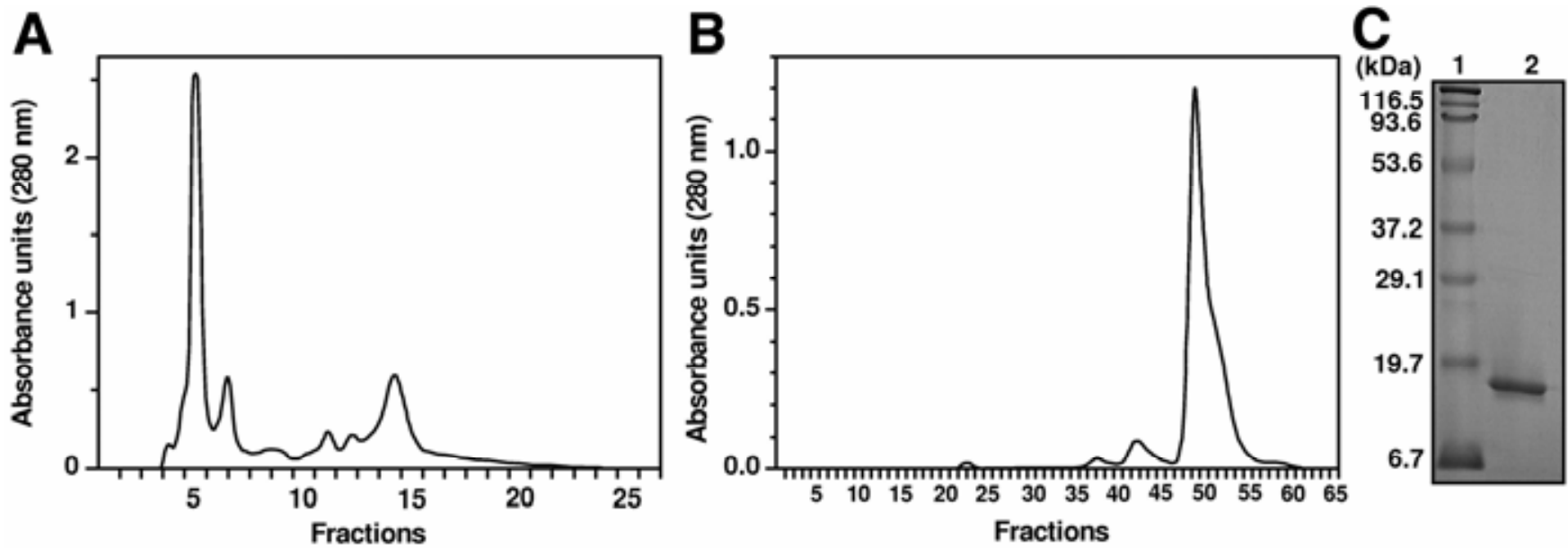

Fig. 5. Purification of native Sm1 from culture filtrates of Trichoderma virens Gv29-8. A, Anion exchange chromatography of concentrated culture filtrate loaded on Sepharose Q column. The divisions on the $x$ axis indicate 5-ml elution fractions. The fraction containing Sm1 (\# 5) was dialyzed, concentrated, and applied to the Superdex 200 column. B, Gel filtration chromatography; the column (Superdex 200) was eluted with $50 \mathrm{mM}$ Tris and $100 \mathrm{mM} \mathrm{NaCl}$ at a flow rate of $0.5 \mathrm{ml} / \mathrm{min}$. The divisions on the $x$ axis indicate 2-ml elution fractions. The 2-ml fractions 48 to 54 (the major peak) were analyzed for protein purity by sodium dodecyl sulfate polyacrylamide gel electrophoresis (SDS-PAGE) (13.5\%) analysis followed by C, Coomassie staining. A single band of Sm1 $(2 \mu \mathrm{g})$ was detected, indicating a pure protein (lane 2). Lane 1, molecular mass marker: prestained SDS-PAGE broad range standards (Bio-Rad). 
Finally, to assess the biological relevance of these results, we sought to determine whether the defense response detected after treatment with Sm1 reflected the plant reaction to the living fungus. The ability of $T$. virens to induce the expression of plant defense genes, such as $G L U$ and $C H T$, in hydroponically grown cotton was examined. As observed in Sm1-induced cotton (Figs. 8 and 9), expression of both PR genes was upregu- lated in the plants growing in coculture with $T$. virens compared with the plants growing alone (Fig. 10).

Sm1 induces resistance against a foliar pathogen of cotton.

In order to assess the disease resistance of cotton plants pretreated with $\mathrm{Sm} 1$, a detached-cotyledon assay was carried out with an isolate of Colletotrichum used as a pathogen. Cotyle-
A

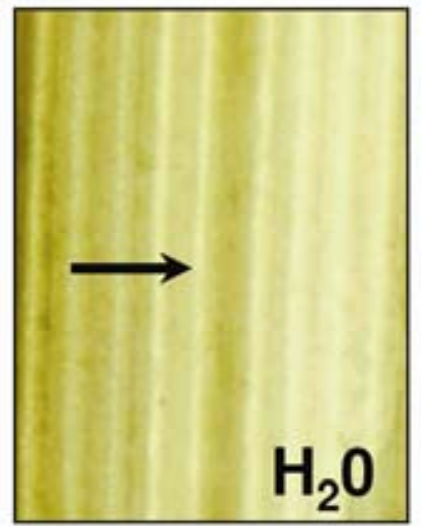

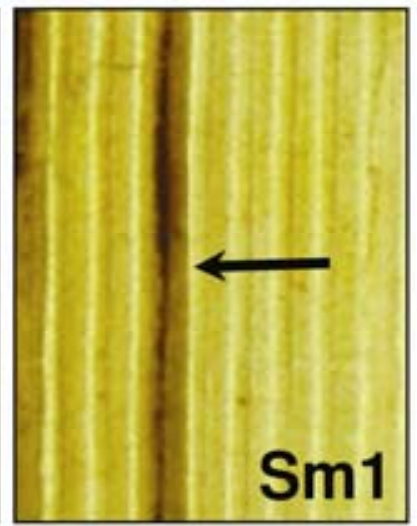

B

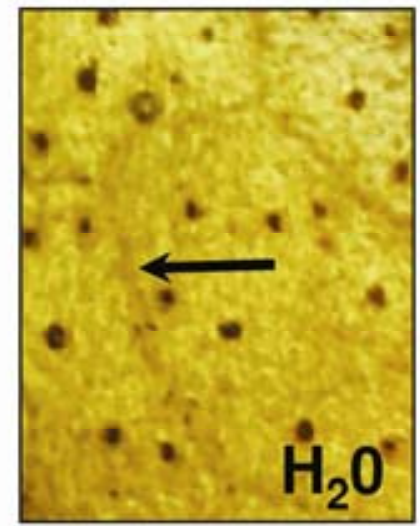

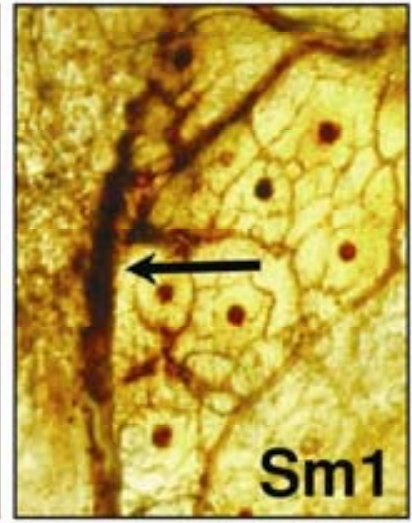

Fig. 6. $\mathrm{H}_{2} \mathrm{O}_{2}$ accumulation in rice and cotton. A, Rice leaves or $\mathbf{B}$, cotton cotyledons were treated with $\mathrm{Sm} 1$ ( $\left.1 \mathrm{nmol}\right)$ or $\mathrm{H}_{2} \mathrm{O}$ (negative control). Treated tissues were harvested $24 \mathrm{~h}$ after treatment, and excised leaf or cotyledon sections were infiltrated with a solution of 3,3'-diaminobenzidine (DAB). In the presence of $\mathrm{H}_{2} \mathrm{O}_{2}$, DAB polymerizes, forming a dark red-brown precipitate staining the leaf vines (indicated by arrows). Microscopy was performed using Olympus Stereoscope SZX-9 at $\times 40$ magnification.
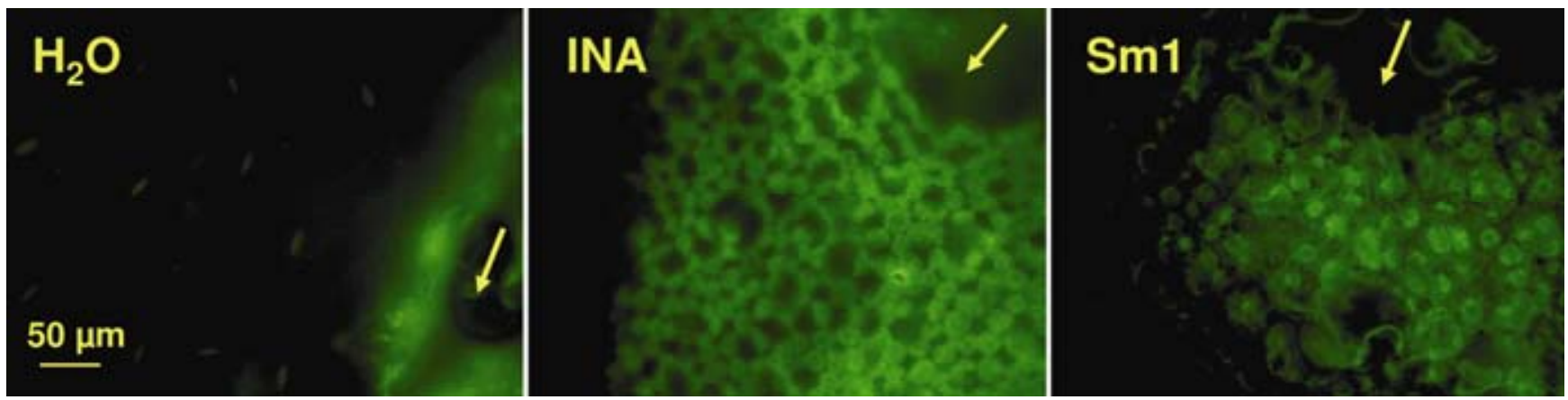

Fig. 7. Induction of autofluorescence in cotton cotyledons. Droplets of Sm1 (1nmol), 2,6-dichloroisonicotinic acid (INA; 52 nmol, positive control), or water (negative control) were placed on the upper surface of slightly punctured cotyledons. Presence of autofluorescence in treated cotyledons was assessed after $24 \mathrm{~h}$ of incubation. Micrographs are centered on the treated region surrounding the application area (indicated by arrows). Microscopy was performed using Olympus BX-51 fluorescent microscope with excitation from 470 to $490 \mathrm{~nm}$, emission from 510 to $550 \mathrm{~nm}$, and $\times 200 \mathrm{magnification}$.

Table 1. List of primers of the cotton defense genes used in RT-PCR and their sources

\begin{tabular}{|c|c|c|c|c|}
\hline Primer name & Sequence $\left(5^{\prime}\right.$ to $\left.3^{\prime}\right)$ & Gene amplified & $\begin{array}{c}\text { Product size (bp) } \\
\text { cDNA }\end{array}$ & Primers source $^{a}$ \\
\hline CHTf & ACCAAGCTACTCGCAAGAGG & & & \\
\hline $\mathrm{CHTr}$ & CGGAAGCGCAGTAAGATGA & Pathogen-induced class I chitinase & 158 & CD485880 \\
\hline GLUf & CATTGATATGACCTTGATCG & & & \\
\hline GLUr & GTGAGATATCCCTTGGATTG & Pathogen-induced glucanase & 171 & CD486342 \\
\hline CAD1-Cf & ATAAGGATGAAATGCGTCC & & & \\
\hline CAD1-Cr & GAAGCTTGGTAAAGTTCCA & Elicitor-induced $\delta$-cadinene synthase & 433 & Chen et.al. 1995 \\
\hline HMGf & GATTTGAAGTTGTATTTGGAG & & & \\
\hline HMGr & GAAATCAGTTTGAAGGAAA & Pathogen-induced HMG-CoA reductase & 216 & CD486522 \\
\hline POD6f & CGCTGCTCGTGATTCTGTAG & & & \\
\hline POD6r & CCTGTGTCCAATCCAATCCT & Pathogen-induced class III peroxidase & 362 & Delannoy et al. 2003 \\
\hline LOX1f & GCATGGAGGACTGATGAAGAGTT & & & \\
\hline LOX1r & GCATGGAAGGCTGAAGCCACCCATAT & Pathogen-induced lipoxygenase & 1,060 & Jalloul et al. 2002 \\
\hline ACTf & CCTCCGTCTAGACCTTGCTG & & & \\
\hline $\mathrm{ACTr}$ & TCATTCGGTCAGCAATACCA & Gossypium hirsutum actin $A C T 9$ & 416 & AY305737 \\
\hline
\end{tabular}

${ }^{\text {a }}$ Primer pairs used for amplification of $C H T, G L U, H M G$, and $A C T$ gene fragments were designed based on the sequences of pathogen- or elicitor-induced cotton or other plant genes available in the GenBank database, and the corresponding accession number is indicated. The sequence of primer pairs used for amplification of $C A D 1-C, P O D 6$, and $L O X 1$ gene fragments were obtained from the studies cited. 
dons were inoculated with the pathogen $24 \mathrm{~h}$ after applying 5$\mu$ droplet of Sm1 $(0.5 \mathrm{nmol} /$ cotyledon $)$, SA ( $25 \mathrm{nmol} /$ cotyledon; positive control), or water (negative control) to the cut petiole. Control plants not treated with Sm1 or SA began

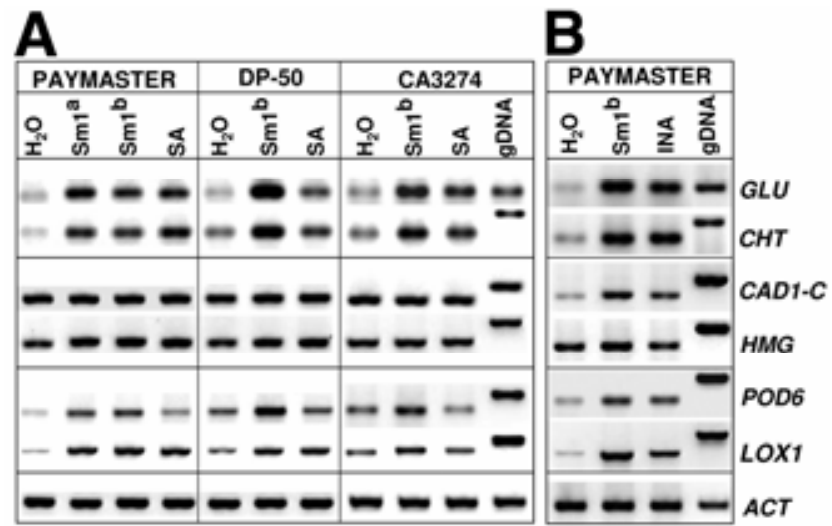

Fig. 8. Defense-related gene expression induced by $\mathrm{Sm} 1$ treatment locally in $\mathbf{A}$, cotton roots $12 \mathrm{~h}$ after treatment or $\mathbf{B}$, cotton cotyledons $24 \mathrm{~h}$ after treatment. A, Two different Gossypium hirsutum cultivars, Paymaster 2326 BG/RR and Deltapine-50, and a breeding line, CA3274, were used (listed on the top). Two-day-old cotton roots were sprayed with $\mathrm{H}_{2} \mathrm{O}$ (negative control), salicylic acid (SA; $75 \mathrm{nmol} /$ root, positive control), or pure $\mathrm{Sm} 1$ (1.2 or $0.6 \mathrm{nmol} / \operatorname{root}\left[\mathrm{Sm} 1^{\mathrm{b}}\right.$ or $\mathrm{Sm} 1^{\mathrm{a}}$, respectively]). B, Cut petioles of 1 week-old cotton cv. Paymaster cotyledons were treated with a 5- $\mu$ d droplet of water, Sm1 (1 nmol), or 2,6-dichloroisonicotinic acid (INA; $52 \mathrm{nmol}$ ). Expression of defense genes was analyzed by semiquantitative reversetranscriptase polymerase chain reaction analysis. Gene-specific primers for the following cotton defense genes were: $G L U$ ( $\beta$-1,3-glucanase), $C H T$ (chitinase), $C A D 1-C(+)-\delta$-cadinene synthase), $H M G$ (3-hydroxy-3-methylglutaryl CoA reductase), POD6 (peroxidase), and GhLOX1 (lipoxygenase). Cotton actin gene $(A C T)$ was used as control for equal amounts of cDNA. For positive control, genomic DNA (gDNA) was included.

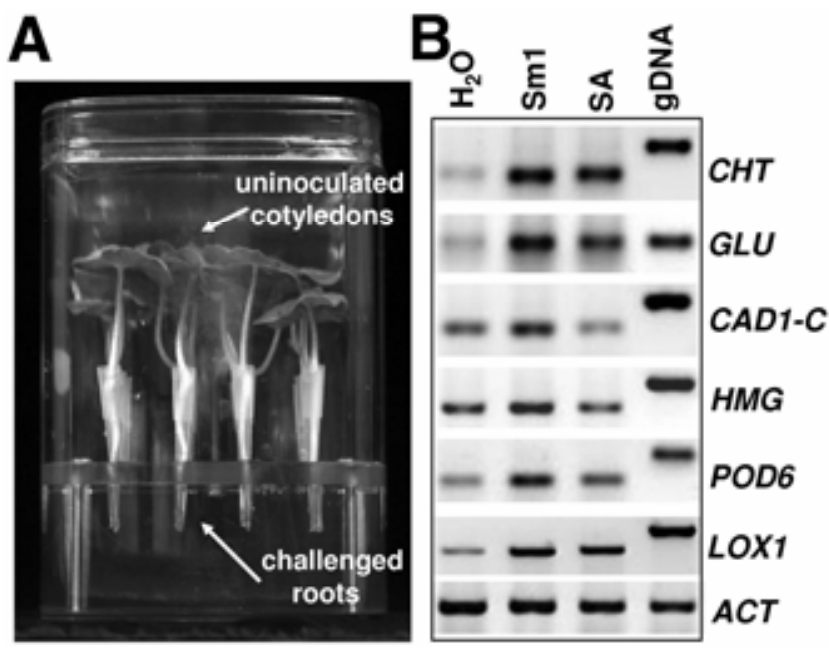

Fig. 9. Cotton defense-related gene expression induced by Sm1 treatment systemically. A, Experimental design for testing systemic induction of cotton defense genes. Four-day-old seedlings were placed into new vials containing $0.2 \mathrm{ml}$ of sterile water, $3.2 \mathrm{nmol}$ of $\mathrm{Sm} 1$, and $600 \mathrm{nmol}$ of salicylic acid (SA). After $24 \mathrm{~h}$ of elicitation, the root and the distal cotyledons (indicated by arrows) were harvested separately and total RNA extracted. B, Defenserelated gene expression was analyzed in the nontreated cotyledons $24 \mathrm{~h}$ after application of the treatments to the roots. Expression of defense genes was analyzed by semiquantitative reverse-transcriptase polymerase chain reaction analysis. Gene-specific primers for the following cotton defense genes were: $G L U$ ( $\beta$-1,3-glucanase), $C H T$ (chitinase), $C A D 1-C(+)-\delta$-cadinene synthase), $H M G$ (3-hydroxy-3-methylglutaryl CoA reductase), POD6 (peroxidase), and GhLOX1 (lipoxygenase). Cotton actin gene ( $A C T)$ was used as control for equal amounts of cDNA. For positive control, genomic DNA (gDNA) was included. showing symptoms in the form of water-soaking lesions within 5 days. Disease assessment was conducted 10 days following the inoculation (Fig. 11); whereas, 12 days after inoculation, the symptomatic tissue collapsed and disintegrated, so that no disease progress was observed thereafter (data not shown). In contrast to typical water-soaking lesions observed in water-treated cotyledons, disease protection was evident in cotyledons treated with Sm1, because almost no lesion development could be observed in those plants (Fig. 11, bottom panel). Finally, the mean lesion area exhibiting symptoms in control plants $\left(1.35 \mathrm{~cm}^{2}\right)$ was significantly higher than in plants treated with $\mathrm{Sm} 1(0.05$ $\left.\mathrm{cm}^{2}\right)$ or SA $\left(0.13 \mathrm{~cm}^{2}\right)$ (Fig. 11, upper panel). The results confirm that purified Sm1 is able to induce resistance to a foliar pathogen in cotton. The high level of protection resulting from the relatively low dose of protein applied $(0.5 \mathrm{nmol})$ substantiates the concept that $\mathrm{Sm} 1$ is an effective elicitor.

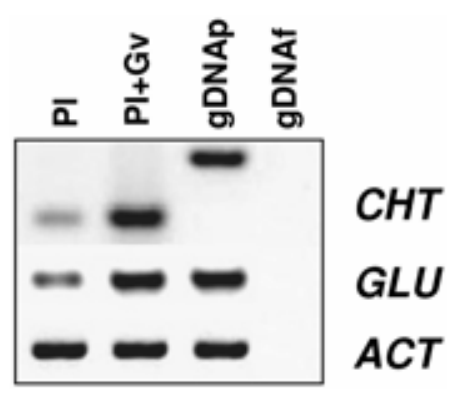

Fig. 10. Induction of cotton defense related genes by coculture with Trichoderma virens. Expression analysis of pathogenesis-related (PRs) genes, $C H T$ (chitinase), and $G L U$ ( $\beta$-1,3-glucanase) in roots of cotton seedlings grown without $(\mathrm{Pl})$ or with $T$. virens $\mathrm{Gv} 29.8(\mathrm{Pl}+\mathrm{Gv})$ in the hydroponic growth system (See Figure 4 for treatments). Expression of defense genes was analyzed by semiquantitative reverse-transcriptase polymerase chain reaction analysis. Gene-specific primers for the following cotton defense genes were $G L U$ ( $\beta$-1,3-glucanase) and $C H T$ (chitinase). Cotton actin gene $(A C T)$ was used as control for equal amounts of cDNA. For positive control, genomic DNA (gDNA) was included.

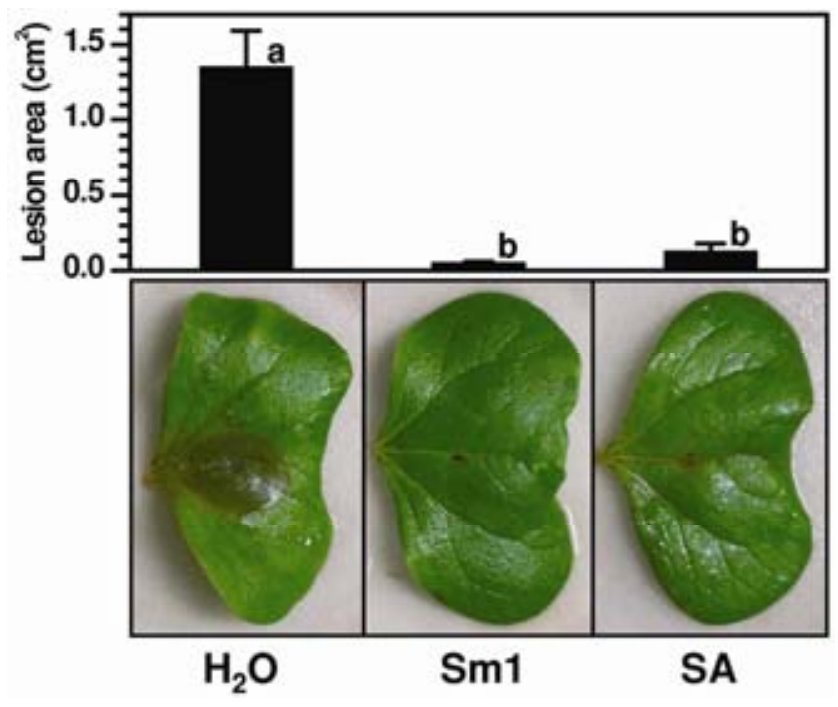

Fig. 11. Effect of Sm1 application on fungal disease protection. Detached cotton cotyledons were inoculated with an isolate of a Colletotrichum sp. $24 \mathrm{~h}$ after applying a 5- $\mu \mathrm{l}$ droplet of water (negative control), Sm1 (0.5 $\mathrm{nmol} /$ cotyledon), or salicylic acid (SA; $25 \mathrm{nmol} /$ cotyledon, positive control) to the cut petiole. The graph illustrates the levels of disease protection observed in each treatment. The mean lesion area was evaluated and photographed 10 days postinoculation. Each bar represents the mean \pm standard error of 14 plants. Columns with letter in common did not differ significantly according to Fisher's protected least significant difference test at a significance level of $5 \%$. 


\section{DISCUSSION}

\section{$\mathrm{Sm} 1$ is a member of the cerato-platanin family.}

Small, cysteine-rich proteins (including avirulence gene products, elicitins, and hydrophobins) have been proposed to play important roles in the specificity, recognition, and adhesion of some symbiotic fungi (Tagu et al. 2002; Templeton et al. 1994; Wosten 2001). Recently, a new family of hydrophobin-like proteins has been described based on the toxin ceratoplatanin from the tree pathogen Ceratocystis fimbriata f. sp. platani (Pazzagli et al. 1999). The family consists of small (approximately 150 amino acids) secreted proteins, mainly associated with toxicity and infection processes, produced by plant and human fungal pathogens (Hall et al. 1999; Hemmann et al. 1997; Pan and Cole 1995; Pazzagli et al. 1999; Wilson et al. 2002). Despite the difference in total number of conserved cysteines (eight in hydrophobins and four in cerato-platanins), the cerato-platanin family shares several features in common with the hydrophobins, such as low molecular weight, moderate to high hydrophobicity, and presence of an amino-terminal secretion signal (Marchler-Bauer and Bryant 2004; Wosten 2001).

Here, we report the purification and functional characterization of Sm1, a 12.6-kDa protein isolated from culture filtrates of $T$. virens. As deduced from the characteristics of the purified protein and its amino acid sequence, Sm1 has all the features described for the cerato-platanin family: size, hydrophobicity, signal peptide, and conserved cysteine pattern. Sequence alignments of conserved domains confirmed that $\mathrm{Sm} 1$ belongs to this family $(E$ value $=2 \mathrm{e}-43)$.

\section{Sm1 is not a toxin but displays strong elicitor activity.}

Because members of this family are associated with toxicity, we first determined whether pure Sm1 in its native form displayed toxic activity toward other microbes or plants. Antibiotic or toxic effects were not observed against any of the diverse collection of bacteria or fungi tested. Additionally, no necrosis was found in any of the different plants treated with Sm1 (cotton, rice, tobacco, and peanut), even when high doses were applied $(10 \mathrm{nmol})$. This is in contrast to cerato-platanin, because an application of $0.8 \mathrm{nmol}$ of the purified protein was sufficient to induce leaf cell necrosis (Pazzagli et al. 1999).

Similar to $\mathrm{Sm} 1$ produced by the avirulent $T$. virens, only a few members of the cerato-platanin family are produced by nonpathogens. For example, Sm1 has high similarity (70\%) to an immunomodulatory protein (Aca1) from the nonpathogen Antrodia camphorate, used in traditional Chinese medicine for treating cancer and inflammation (Hsu et al. 2005). In planta, fungal metabolites from nonpathogens have been shown to elicit plant defense responses and increase resistance against various pathogens without the induction of hypersensitive response or necrosis in the host (Chang et al. 1997; Madi and Katan 1998). Because T. virens is shown to induce plant resistance (Howell et al. 2000), we tested the capacity of Sm1 to act as an elicitor of plant defense reactions.

We examined early cellular events in plant-elicitor interactions such as the generation of reactive oxygen species (ROS) during the oxidative burst (Mittler et al. 2004). ROS control multiple cellular functions in plants, including the oxidative cross-linking of cell-wall proteins, alteration of the redox status to regulate specific plant transcription factors and direct antimicrobial activity, and initiation of the hypersensitive response (HR) (Bolwell and Wojtaszek 1997; Bowler and Fluhr 2000; Mittler et al. 2004). Sm1 induced significant production of $\mathrm{H}_{2} \mathrm{O}_{2}$ in both rice and cotton leaves (Fig. 6), but did not cause HR-associated necrotic lesions. Previous studies have demonstrated that resistance and extracellular accumulation of
ROS are not necessarily associated with HR (Baker and Orlandi 1995; Glazener et al. 1996). Another early event associated with a plant response to pathogen attack is accumulation and oxidation of phenolic compounds such as phytoalexins and lignin, usually associated with autofluorescence of these compounds (Heath 2000; Nicholson and Hammershmidt 1992). Cerato-platanin was shown to induce autofluorescence $24 \mathrm{~h}$ after infiltration into tobacco leaves (Pazzagli et al. 1999). Similarly, Sm1 induced a significant autofluorescence response when applied to cotton cotyledons (Fig. 7). The dose applied (1 nmol) was comparable to that reported for cerato-platanin, elicitins, and other elicitors (Huet et al. 1995; Pazzagli et al. 1999; Scala et al. 2004).

We also investigated the transcriptional regulation of plant defense mechanisms in response to Sm1. Upland cotton $(G$. hirsutum) was chosen as the host plant because $T$. virens is rhizosphere competent on cotton, and the induction of phytoalexins and peroxidase activity in cotton roots treated with $T$. virens protein fractions have been reported (Hanson and Howell 2004). PR proteins often are used as markers of plant response to pathogens and their elicitor molecules (Bowles 1990; Somssich and Hahlbrock 1998). Recently, a large number of PR genes, including those encoding for glucanases and chitinases, have been identified in cotton upon infection with $F$. oxysporum (Dowd et al. 2004). In our study, both glucanase and chitinase genes were highly induced in all cotton genotypes, both locally and systemically, in response to Sm1 (Fig. 8). Remarkably, Sm1 elicitation caused a stronger upregulation of glucanase and chitinase than the treatment with SA in Deltapine-50.

Peroxidases also are related to resistance responses, including lignification and suberization, cross-linking of cell wall proteins, generation of ROS, and phytoalexin synthesis, and they posses antifungal activity themselves (Bolwell and Wojtaszek 1997; Caruso et al. 2001; Quiroga et al. 2000; Sasaki et al. 2004). Recently, several different peroxidases were cloned and studied in cotton plants during compatible and incompatible interactions with the bacterial pathogen $X$. campestris pv. malvacearum (Delannoy et al. 2003). Among them, POD6 appeared to be related to resistance. In our study, POD6 was induced by $\mathrm{Sm} 1$, both locally and systemically, and only slightly induced by water or SA. Evidence for an SA-independent regulation of defense-related peroxidases has been reported previously (Martinez et al, 2000, Sasaki et al. 2004). Similarly, the involvement of lipoxygenases in conferring resistance against pathogens has been demonstrated for several plant-pathogen systems, including cotton-X. campestris pv. malvacearum (Feussner and Wasternack 2002; Jalloul et al. 2002; Rance et al. 1998; Wilson et al. 2001). Here we show that $L O X 1$, as with POD6, is upregulated after application of Sm1, both locally and systemically.

Several cotton sesquiterpenoids, with known fungistatic properties and insecticidal activities, can be induced by pathogen infection (Abraham et al. 1999; Chen et al. 1995, 1996; Stipanovic et al. 1999; Tan et al. 2000), but also by interaction with avirulent Trichoderma strains (Howell et al. 2000). We have investigated the transcriptional regulation of two genes encoding major enzymes of the mevalonate pathway leading to sesquiterpenoid biosynthesis in cotton, $\mathrm{HMG}-\mathrm{CoA}$ reductase $(H M G)$ and $(+)-\delta$-cadinene synthase $(C A D 1-C)$, upon Sm1 elicitation. Expression of both genes was induced by $\mathrm{Sm} 1$ in cotton cotyledon tissue both locally and systemically. Induction of these genes correlates well with the reported induction of phytoalexins (Hanson and Howell 2004) and with the observed autofluorescence response. Recently, induction of phytoalexin synthesis by cerato-platanin in host and nonhost plants also has been shown (Scala et al. 2004). 
In summary, all bioassays performed confirmed that Sm1 constitutes an effective elicitor of plant defense responses, acting either locally at the site of application or systemically in distant tissues.

\section{$\mathrm{Sm1}$ induces disease resistance.}

We tested the ability of purified Sm1 to protect cotton cotyledons from infection and colonization by a Colletotrichum $\mathrm{sp}$, the causal agent of anthracnose, a common and destructive disease on numerous crops (Prusky et al. 2000). Our results demonstrated that Sm1 was able to highly protect cotton cotyledons from infection and colonization by Colletotrichum sp. Remarkably, whereas, in water-treated controls, the disease progressed daily and finally caused degradation of the infected tissue, the disease in Sm1-pretreated cotyledons was almost completely blocked or highly reduced because water-soaking lesions were either absent or very minimal throughout the whole period. This clear effect of Sm1 in cotton resistance to Colletotrichum sp., and the described activation by $\mathrm{Sm} 1$ of defense-related gene expression, production of ROS, and phenolics, confirms that Sm1 induces disease resistance. Furthermore, the absence of direct effect on the pathogens and the lack of phytotoxicity satisfy the requirements of Sm1 as an elicitor of plant-induced systemic resistance (Friedrich et al. 1996; Ward et al. 1991).

\section{$S M 1$ is transcriptionally regulated \\ during Trichoderma sp.-plant interaction.}

SM1 expression seems to be subject to complex regulation, both during development and in response to external stimuli. It is remarkable that SMI expression was detected in every media and developmental stages analyzed. Although only a weak regulation by carbon sources of SMI expression was observed in liquid media, the induction by carbon starvation and transient repression in media containing carbon may indicate catabolic repression, further supported by the data of gene expression from solid media. This repression is coherent with the presence in the promoter region of putative cis-acting elements involved in carbon regulation. Because the soil is generally considered to be a nutritionally sparse environment, SMI expression is expected to be derepressed in exploratory mycelia of Trichoderma spp. The presence of several other putative regulatory sequences in the promoter region, such as $\mathrm{pH}$ and stress response elements, also is consistent with a complex transcriptional regulation and deserves further experimental analysis. In contrast to most Trichoderma genes involved in mycoparasitism (Baek et al. 1999; Cortés et al. 1998; Pozo et al. 2004), expression of SM1 is not significantly induced by the presence of cell walls from a fungal host (Rhizoctonia spp.) during simulated parasitism. Indeed, only two of the four putative mycoparasitism responsive elements (MYRE) described in Trichoderma cell-wall-degrading enzymes (Cortes et al. 1998) were found in the SMI promoter. The low induction in gene expression in the presence of a fungal host and the lack of enzymatic or toxic activity do not support a direct role of Sm1 in mycoparasitism.

Analysis of SM1 transcript levels during different fungal developmental stages in vitro revealed that the gene was expressed in all developmental stages tested, with higher expression during mycelial growth and conidiation than in germinating spores. Developing or sporulating mycelia are actively growing structures and, in rhizosphere-competent fungi, these are the structures that most likely will establish contact with its host plant. Using a hydroponic system that allows coculture of Trichoderma spp. and cotton seedlings, we have shown the induction of SMI transcription in the presence of a host plant, coupled with higher Sm1 protein levels in the medium. Our re- sults, namely, the large amount of protein secreted, the ability of Sm1 to act as an elicitor of plant defense reactions and disease resistance, and the induction of SMI expression during growth in the presence of a host plant, indicate the role of Sm1 in the plant-fungus interaction. Recently, immunolocalization of cerato-platanin protein in Ceratocystis fimbriata showed that, in addition to being released abundantly into media, the protein is located in the cell walls of ascospores, hyphae, and conidia, as described for hydrophobins (Boddi et al. 2004). The localization at the fungal surface and the ability to induce defense reactions is consistent with a primary role involving direct contact with the plant recognition system. The role of hydrophobins in several mutualistic symbioses has been reported, including those established between fungi and plants, and algae and cyanobacteria (Honegger 1991; Scherrer et al. 2000; Tagu et al. 1996). For example, a role for hydrophobins hydPt-1 and hydPt has been proposed during early stages of Pisolithus-Eucalyptus ectomycorrhizae formation, related to the adhesion of the mycelium to the root surface (Tagu et al. 1996). Interestingly, transcripts coding for a homolog of the cerato-platanin SnodProt1 protein were among the most abundant in the free-living mycelium of this ectomycorrhizal fungus (Pisolithus microcarpus) (Peter et al. 2003). Recently, transcriptional regulation of this gene (SnodProt1) during the establishment and functioning of the mycorrhizal association has been demonstrated (Duplessis et al. 2005). There is, therefore, strong indications supporting the role of these types of molecules, including Sm1, in fungus-plant interactions.

In summary, the importance of induction of plant defense responses by Trichoderma spp. in biocontrol is now widely accepted; however, the process is largely undefined compared with the well-documented responses by other beneficial organisms such as rhizobacteria (Pieterse et al. 2003). The ability of $\mathrm{Sm} 1$ to act as an elicitor of plant defense reactions and to confer protection toward fungal pathogen strongly support a key role of Sm1 in Trichoderma-induced systemic resistance. This is, to our knowledge, the first report of the cloning, purification, and characterization of a proteinaceous elicitor from this group of rhizosphere competent Trichoderma spp. Sm1 deletion and overexpression strains currently are being characterized, and fusion of Sm1 with the green fluorescent protein is underway to determine cellular localization of the protein within the fungus and during interaction with the plant (S. Djonović, A. Wiest, and C. M. Kenerley, unpublished). The spectrum of effectiveness of Trichoderma spp.-induced systemic resistance and the defense reactions triggered by $\mathrm{Sm} 1$ combined with the potential of increasing induced resistance to seedling pathogens by $S M 1$ overexpressing strains may offer new directions for the biocontrol of plant pathogens.

\section{MATERIALS AND METHODS}

\section{Fungus and plant materials.}

Strain of T. virens Gv29-8 (Baek and Kenerley 1998) and an isolate of Colletotrichum sp. were used in this study. The strains were routinely maintained on PDA (Difco Laboratories, Detroit).

Plants used for elicitor activity tests were rice (Oryza sativa cv. M-202), two cotton (G. hirsutum) cultivars, Paymaster 2326 BG/RR and Deltapine-50, and the cotton breeding line CA3274. For phytotoxicity tests, leaves of approximately 3week-old cotton ( $G$. hirsutum cv. Paymaster 2326 BG/RR), rice (O. sativa cv. M-202), tobacco (Nicotiana tabacum $\mathrm{cv}$. Glurk), and peanut (Arachis hypogaea cv. Flowrunner) were used. Cotyledons of 10-day-old cotton seedlings (G. hirsutum cv. Paymaster 2326 BG/RR) were used in Colletotrichum sp. resistance detached cotyledons assays. 
Plant-fungus coculture filtrates

from a hydroponic growth system.

We have developed a hydroponic system similar to the one described by Yedidia and colleagues (Viterbo et al. 2004; Yedidia et al. 1999) to evaluate the resistance response of cotton seedlings stimulated by $T$. virens. Polycarbonate culture boxes (10.9 by 10.9 by $15.7 \mathrm{~cm}$; Lifeguard; Sigma) each were provided with a polycarbonate stand to support 16 seedlings approximately $1 \mathrm{~cm}$ above the level of the growth medium (300 $\mathrm{ml})$. Plant nutrient solution was half-strength Murashige and Skoog (MS) basal medium amended with Gamborg's vitamins ( $\mathrm{pH}=5.6$ ) (Sigma-Aldrich, St. Louis). Seed were surface sterilized according to Dowd and associates (2004). Treated seed were placed in sterile petri dishes containing moistened filter paper and incubated in the dark for 2 days at $27^{\circ} \mathrm{C}$ to allow germination. Germinated seed with similar-sized roots were placed on the polycarbonate stands in each culture box. The aseptic boxes were maintained in a controlled environment at $23 \pm 1^{\circ} \mathrm{C}$ and a $14-\mathrm{h}$ photoperiod with slight agitation on the rotary shaker $(45 \mathrm{rpm})$.

The mycelial inoculum of $T$. virens Gv29-8 was prepared by inoculating $100 \mathrm{ml}$ of GYEC media (Thomas and Kenerley 1989) with $3 \times 10^{7}$ spores $/ \mathrm{ml}$ and incubating for $24 \mathrm{~h}$ on a rotary shaker at $120 \mathrm{rpm}$ and $23^{\circ} \mathrm{C}$. The mycelia were harvested on two layers of sterile Miracloth (Calbiochem, San Diego, CA, U.S.A.), washed with $200 \mathrm{ml}$ of sterile water, and inoculated aseptically into $300 \mathrm{ml}$ of MS medium containing 6-dayold cotton seedlings. For Trichoderma spp. growing in the absence of cotton seedlings, MS, supplemented with $0.05 \%$ sucrose (300 $\mathrm{ml}$ of medium) was inoculated with the same mycelial biomass. Control plants were grown in $300 \mathrm{ml}$ of MS medium without Trichoderma spp. In treatments of control plants and plants inoculated with the fungus, the growth medium was replaced with fresh MS to reduce the extracellular proteins accumulated during plant growth. Two days later, media from all treatments was collected, filtered through a $10-\mu \mathrm{m}$ NITEX nylon cloth, and $10 \mathrm{ml}$ of each treatment was concentrated by using 10-kDa cutoff Millipore microcon filter devices (Bedford, MA, U.S.A.).

\section{N-terminal sequencing and antibody production.}

The identified protein band (Sm1) was excised and electroeluted in the Electroeluter 422 (Bio-Rad, Hercules, CA, U.S.A.). This fraction was used to produce a polyclonal antibody in rabbits (Sigma, Woodlands, TX, U.S.A.). N-terminal sequencing of the protein was performed by automated Edman chemistry on a Hewlett Packard G1005A Protein Sequencher (Protein Chemistry Laboratory, Texas A\&M University).

Computational protein analyses were performed using the ExPASy proteome server at the Swiss Institute of Bioinformatics and EMBOSS at the European Bioinformatics Institute. Multiple sequence alignments were performed using ClustalW at the Kyoto University Bioinformatics Center.

\section{Cloning of the SM1 gene.}

The sequence of the first 44 amino acid residues obtained by $\mathrm{N}$-terminal sequencing was blasted against GenBank and a $T$. reseei $\mathrm{EST}$ database. After similarity searches were performed, the homologous nucleotide sequence of a $T$. reseei EST was used to design specific primers for PCR amplification of $T$. virens genomic DNA. The nucleotide sequences of primers were forward, 5'-GTCTCCTACGACACCGGCTA-3' (SmF), and reverse 5'-GTCGAGCGCAATGTTGAA-3' (SmR). $T$. virens genomic DNA, isolated as described previously (Xu et al. 1996), was PCR amplified using an Invitrogen Taq DNA polymerase kit (Carlsbad, CA, U.S.A.). The 264-bp SmF-SmR PCR product subsequently was purified (MinElute PCR purifi- cation kit, Valencia, CA, U.S.A.) and sequenced. The purified product was used to probe our T. virens BAC library (Grzegorski 2001) and 33 positive BAC clones were identified. One of the positive clones was further digested with several restriction enzymes and the fragments subcloned into a pBluescript II SK (+ or - ) vector. Sequencing of the subclones was performed by a primer-walking strategy (Sambrook et al. 1989). All sequencing reactions were performed at the Gene Technologies Laboratory (Texas A\&M University). DNA sequences were analyzed by DNA Strider 1.2 (Marck 1988), and Sequencher 4.1 (GCC, Ann Arbor, MI, U.S.A.).

\section{SM1 gene expression analysis.}

Gene expression analysis was performed with fungal tissue grown under different environmental and developmental conditions and in the presence of cotton seedlings.

To assess nutritional regulation of $S M 1$, Vogel's minimal medium (Vogel 1956) without a carbon source (VM) or supplemented with either $1.5 \%$ glucose (VMG) or $0.5 \%$ fungal cell walls from Rhizoctonia solani (VMR) as carbon sources was used (Pozo et al. 2004). Cell walls of Rhizoctonia solani as the sole carbon source were used to simulate mycoparasitic conditions and were prepared according to Ren and West (1992). To study SM1 expression during different developmental stages of fungal growth, samples included: germinating spores (GS); nonsporulating mycelia (nSM) and sporulating mycelia (SM) grown on solid VMS or PDA medium; mycelia grown in liquid VMS medium; and mycelia of $T$. virens indirectly confronting Rhizoctonia solani mycelia (Cortes et al. 1998; McLeod et al. 2003; van West et al. 1998). For GS stage, the conidia were obtained from 5-day-old cultures on PDA by gently rubbing with a sterile glass rod and collecting the conidia by centrifugation at $5,000 \mathrm{rpm}$ for $3 \mathrm{~min}$. Collected spores were spread onto cellophane covering VMS or PDA and incubated for $12 \mathrm{~h}$ at $27^{\circ} \mathrm{C}$ in the dark to allow germination. After the incubation period, the spores were scraped off the cellophane, frozen in liquid nitrogen, and stored at $-80^{\circ} \mathrm{C}$ until RNA extraction. For the nSM developmental stage, a mycelial plug from a 5-day-old PDA culture was inoculated onto cellophane overlaying VMS or PDA, incubated at $27^{\circ} \mathrm{C}$ for 2 days in the dark, and then harvested. For the SM stage, mycelia were collected after 5 days of growth on VMS and PDA plates. To obtain mycelia grown in liquid VMS medium, Gv29-8 at $10^{6}$ spores/ml (final concentration) was inoculated and then incubated for 5 days at room temperature with shaking at $160 \mathrm{rpm}$. The indirect confrontation assay was performed as described by Cortes and associates (1998). Briefly, a plug of Rhizoctonia solani was covered with two cellophane disks before placing a $T$. virens agar plug on top. After approximately 3 days of growth at $27^{\circ} \mathrm{C}$ in the dark, the approximately 1-cm-overlapping mycelia of $T$. virens and Rhizoctonia solani were recovered and harvested separately. All the samples were frozen immediately in liquid nitrogen.

A hydroponic system (described above) was used to compare the expression of $S M 1$ in the fungus growing in the presence or absence of cotton seedlings. Cotton seedlings were grown for 6 days, inoculated with a mycelial preparation of Gv29-8, and incubated for $48 \mathrm{~h}$. The mycelia from the culture filtrate and adhering to the roots in the hydroponic culture boxes were collected on $10 \mu \mathrm{m}$ of NITEX nylon cloth.

Total RNA was extracted following the protocol of Jones and associates (1985). SM1 expression under different nutritional conditions and developmental stages was analyzed by Northern blot using the 264-bp (SmF-SmR) PCR product as described below. The blots were reprobed with a $285-\mathrm{kb} \mathrm{NcoI}$ fragment from the serine protease TVSP1 coding region as positive control for mycoparasitism-related regulation (Pozo et al. 2004). For analysis of expression of SMI in the hydroponic 
system, semiquantitative (see later section) RT-PCR analysis was performed. Extracted RNA was DNase treated and cleaned using a DNA-free kit (Ambion, Austin, TX, U.S.A.). Total RNA $(2.5 \mu \mathrm{g})$ was reverse transcribed with First-Strand cDNA Synthesis Kit (G.E. Healthcare, Piscataway, NJ, U.S.A.) using random hexa-mer $\operatorname{pd}(\mathrm{N})_{6}$ as a primer. The $S M 1$ genespecific primers were $\mathrm{SmF}-\mathrm{SmR}$, and the actin-specific primers, used as an internal standard, were forward, 5'-AAGAAGTTG CTGCCCTCGT-3' and reverse, 5'-GCTCAGCCAGGATCTT CATCATC-3'. PCR amplification of SM1 fragments comprised 23 cycles for $S M 1$ (each cycle: $30 \mathrm{~s}$ at $94^{\circ} \mathrm{C}, 20 \mathrm{~s}$ at $5^{\circ} \mathrm{C}$, and $20 \mathrm{~s}$ at $72^{\circ} \mathrm{C}$ ) and 25 cycles for actin (each cycle: $30 \mathrm{~s}$ at $94^{\circ} \mathrm{C}$, $30 \mathrm{~s}$ at $58^{\circ} \mathrm{C}$, and $40 \mathrm{~s}$ at $72^{\circ} \mathrm{C}$ ). For $S M 1$ expression analysis in the hydroponic system, the specificity of primers to Trichoderma spp. was examined by using cotton and Trichoderma genomic DNA. PCR products were electrophoresed on $2 \%$ agarose gels and band intensities compared within each experiment after ethidium bromide staining.

\section{DNA, RNA, and protein gel blot analysis.}

The 264-bp (SmF-SmR) PCR product was used as probe for DNA and RNA gel blot analysis using standard procedures (Sambrook et al. 1989). Hybridizations were performed overnight at $42^{\circ} \mathrm{C}$ using Ultrahyb as hybridization buffer (Ambion).

For Sm1 protein detection, proteins from concentrated samples corresponding to equal volume equivalent to $300 \mathrm{ml}$ of medium from the hydroponic system were electrophoresed on SDS-PAGE gels and electroblotted to a nitrocellulose membrane (Osmonics Inc., Gloucester, MA, U.S.A.). Sm1 protein was detected using Sm1 polyclonal antibodies (dilution 1:1,000) in a standard Western blot procedure (Sambrook et al. 1989).

\section{Sm1 protein purification and mass spectrometry.}

Sm1 was purified from protein extracts of Gv29-8 culture filtrates. The purification procedure consisted of two steps: i) AEX performed using a Sepharose Q column (10 by $20 \mathrm{~cm}$; G.E. Healthcare) and ii) GFC using Superdex200 column (16 by $60 \mathrm{~cm}$; G.E. Healthcare). For AEX, the protein pellet was resuspended in a $2-\mathrm{ml}$ aliquot of $10 \mathrm{mM}$ Tris, $\mathrm{pH}=8.2$, and loaded on a column previously equilibrated with the same buffer. Material bound to the AEX column was eluted using a linear gradient of solvent $\mathrm{A}(10 \mathrm{mM}$ Tris, $\mathrm{pH}=8.2)$ and solvent $\mathrm{B}(1 \mathrm{M} \mathrm{NaCl}, 10 \mathrm{mM}$ Tris, $\mathrm{pH}=8.2)$, at a flow rate of $5 \mathrm{ml} / \mathrm{min}$ with an Acta Explorer 10 (G.E. Healthcare). Sm1 was eluted at approximately $80 \mathrm{mM} \mathrm{NaCl}$. This fraction was pooled, concentrated to $2 \mathrm{ml}$, dialyzed against $50 \mathrm{mM}$ Tris and $100 \mathrm{mM}$ $\mathrm{NaCl}, \mathrm{pH}=7.5$, and chromatographed on a Superdex $200 \mathrm{col}-$ umn previously equilibrated with the same buffer. The Superdex 200 column was calibrated using the following molecular weight (MS) markers: blue dextran (MW 2,000,000), bovine serum albumin (MW 67,000), myoglobine (MW 16,900), aprotinin (MW 6,500), and potassium ferricyanide (MW 329.25). The column was eluted with $50 \mathrm{mM}$ Tris, $100 \mathrm{mM}$ $\mathrm{NaCl}$ at a flow rate of $0.5 \mathrm{ml} / \mathrm{min}$. The Superdex 200 fraction which showed maximum absorbance at $290 \mathrm{~nm}$ was isolated, and 2-ml fractions dialyzed against $10 \mathrm{mM} \mathrm{NH} \mathrm{NCO}_{3}$. After removal of $\mathrm{NH}_{4} \mathrm{HCO}_{3}$ under vacuum, the purity of protein was assessed by gel electrophoresis (SDS-PAGE) followed by silver and Coomassie brilliant blue R-250 staining.

The pure protein then was subjected to MALDI/TOF mass spectrometry (Laboratory for Biological Mass Spectrometry, Texas A\&M University) for the determination of molecular weight.

\section{Enzyme and toxin activity tests.}

Pure Sm1 $(1 \mu \mathrm{g})$ resuspended in water was tested for putative protease, glucanase, and chitinase activity. General and basic protease activities were measured using Hide Azure powder (Calbiochem) and chymotrypsin substrate (Sigma) according to Flores and associates (1997) and Geremia and associates (1993), respectively. $\beta$-1,3-Glucanase and $\beta$-1,6-glucanase activity were determined by liberation of reducing sugars from laminarin and pustulan, respectively (Nelson 1957). For chitinase activity, the procedure of Ren and West (1992) was followed, using the substrates 4-methylumbelliferyl- $\beta$-D- $N, N^{\prime}, N$ triacetylchitotriose (Sigma) for endochitinase and 4-methylumbelliferyl- $\beta$-D-glucosaminide (Sigma) for $n$-acetyl glucosaminidase activity.

Pure Sm1 resuspended in water was bioassayed for toxicity against several plant pathogenic bacteria and fungi as described by Park and associates (1992) and Howell and associates (1993), respectively. Bacteria tested included the gram-positive Clavibacter michiganensis subsp. michiganensis and Bacillus cereus, and the gram-negative $X$. campestris pv. vesicatoria and Agrobacterium tumefaciens. Fungi tested were Mucor hiemalis, Sclerotium rolfsii, Botrytis cinerea, F. oxysporum, Rhizoctonia solani, Cochliobolus heterostrophus, and the Oomycetes Pythium ultimum and Phytophthora infestans. Droplets (10 $\mu \mathrm{l}$ each) containing $0.05,0.1,0.5,1,2,5$, or $10 \mathrm{nmol}$ of Sm1 were applied to each antibiotic disk for inhibition assays.

To assess phytotoxicity of Sm1, leaves of approximately 3week-old cotton, tobacco, peanut, and rice were treated with $0.1,1,2,5$, or $10 \mathrm{nmol}$ of purified $\mathrm{Sm} 1$ protein resuspended in water. The protein was applied either by infiltration $(20 \mu \mathrm{l})$ using a Hagborg (1970) device or as a 3- $\mu$ l droplet after slightly puncturing the leaves with a needle. After 24,48 , and $96 \mathrm{~h}$ of incubation, the leaves were monitored for appearance of necrotic lesions.

\section{Elicitor activity tests: Production of $\mathrm{H}_{2} \mathrm{O}_{2}$ and autofluorescence.}

The production of $\mathrm{H}_{2} \mathrm{O}_{2}$ in 3-week-old rice leaves and 1week-old cotton cotyledons was examined $24 \mathrm{~h}$ after application of $\mathrm{Sm} 1$ (1 nmol) or $\mathrm{H}_{2} \mathrm{O}$ (negative control) following the procedure of Fitzgerald and associates (2004). Briefly, drops $(2 \mu \mathrm{l})$ of $\mathrm{Sm} 1$ or water were placed on the upper surface of the leaves which previously were punctured slightly. Leaves then were vacuum-infiltrated with nitro 3,3'-diaminobenzidine (Sigma), incubated overnight, fixed and cleared in alcoholic lacto-phenol solution, and examined for the formation a redbrown precipitate. Microscopy was performed using an Olympus Stereoscope SZX-9 (Olympus America Inc., Melville, NY, U.S.A.) at $\times 40$ magnification.

To test for autofluorescence, $1 \mathrm{nmol}$ of Sm1, $52 \mathrm{nmol}$ of INA (Sigma), or sterile $\mathrm{H}_{2} \mathrm{O}$ was applied to $G$. hirsutum leaves as described above. After $24 \mathrm{~h}$ of incubation, the induction of autofluorescence in leaves was assessed. Treated leaves were cleared in alcoholic lacto-phenol solution, incubated in $70 \%$ glycerol, and mounted on slides (Fitzgerald et al. 2004). Microscopy was performed using Olympus BX-51 fluorescent microscope (Olympus America Inc.) at $\times 200$ magnification (excitation wavelengths from 470 to $490 \mathrm{~nm}$, emission wavelengths from 510 to $550 \mathrm{~nm}$, and a dichroic mirror at 505).

\section{Elicitation of plant defense genes by Sm1.}

Local induction of plant defense genes by Sm1 was examined in the roots of two different cotton cultivars, $G$. hirsutum cv. Paymaster 2326 BG/RR and Deltapine-50, and the cotton breeding line CA3274. Surface sterilized and pregerminated seed (as described previously) were collected, placed into sterile petri dishes with filter paper, and treated by spraying with a Preval sprayer (Yonkers, NY, U.S.A.). The treatments were sterile $\mathrm{H}_{2} \mathrm{O}$ (negative control), SA (positive control), or pure Sm1. Two different concentrations of Sm1 were tested: 
i) $3 \mathrm{ml}$ containing $12 \mathrm{nmol}$ of $\mathrm{Sm} 1$ was applied to 10 roots placed on a regular plate (100 by $15 \mathrm{~mm})$ to all genotypes and ii) additional lower doses consisting of $5 \mathrm{ml}$ of $8 \mathrm{nmol}$ Sm1 applied to 15 roots in a large plate $(150$ by $15 \mathrm{~mm})$ to cv. Paymaster. For all genotypes, $3 \mathrm{ml}$ containing $750 \mathrm{nmol}$ of SA was applied. Three replications of each treatment were performed. Cotton roots were harvested at 3, 6, 9, 12, 24, and $48 \mathrm{~h}$ after spraying.

Local induction of plant defense genes was determined in cotyledons of 1-week-old Paymaster seedlings. Cotyledons were detached from the seedling and placed into sterile petri dishes containing moistened filter paper. A 5- $\mu \mathrm{l}$ droplet of water, Sm1 (1 nmol), or INA (52 nmol) was applied as a hanging droplet to the cut petiole. The droplets were absorbed within 5 min of application. Additional water droplets were added to prevent the petiole from drying. After $24 \mathrm{~h}$ of incubation, the cotyledon tissue was harvested.

Systemic induction of plant defense genes was assessed using Deltapine-50. Surface sterilized and pregerminated cotton seed were placed into small sterile vials (containing MS medium) held by a polycarbonate stand. The polycarbonate stand, with the cotton roots, then was placed into a sterile polycarbonate culture box. Seedlings were provided with additional growth medium, if needed, on a daily bases. The seedlings were grown at $25^{\circ} \mathrm{C}$ in a 14 -h photoperiod until the cotyledons were fully open ( 2 to 3 days). The seedlings then were transferred to fresh vials containing $0.2 \mathrm{ml}$ of sterile water, 0.2 $\mathrm{ml}$ of water containing $3.2 \mathrm{nmol}$ of Sm1 or $600 \mathrm{nmol}$ of SA per plant. After $24 \mathrm{~h}$, the root and the cotyledons were harvested separately and RNA extracted.

Expression of defense-related genes was analyzed in $G$. hirsutum cv. Paymaster seedlings hydroponically grown with or without $T$. virens. Plant root tissue was harvested from the hydroponic system previously described, after $48 \mathrm{~h}$ of incubation.

All harvested samples were frozen immediately in liquid nitrogen. Total RNA was extracted by the method of Wang and associates (2000).

\section{Expression analysis of cotton defense-related genes.}

Expression of genes corresponding to different plant defense pathways was examined: $G L U$ ( $\beta$-1,3-glucanase), $C H T$ (chitinase), $C A D 1-C((+)-\delta$-cadinene synthase), $H M G$ (3-hydroxy-3methylglutaryl CoA reductase), POD6 (peroxidase), and GhLOX1 (lipoxygenase). G. hirsutum actin gene (ACT) was used as comparison for quantitative gene expression. All primers used in this study are presented in Table 1 . The primers to specifically amplify $H M G, G L U$, and $A C T$ were designed based on available pathogen- or elicitor-induced cotton or other plant gene sequences available in the GenBank database. Primer sequences for $C A D 1-C, P O D 6$, and $G h L O X 1$ were obtained from reports of Chen and associates (1995), Delannoy and associates (2003), and Jalloul and associates (2002), respectively. Following amplification of $G$. hirsutum DNA, PCR products were sequenced to confirm their gene-specific identities. Semiquantitative RT-PCR analysis was employed. To define the optimal number of PCR cycles for linear amplification for each gene, a range of PCR amplifications were performed. Subsequently, PCR products were electrophoresed and stained with ethidium bromide, and band signals quantified by phosphorimaging (Fujifilm BAS 1800 II PhosphorImager, Tokyo). PCR amplification of $G L U, C H T, C A D 1-C, H M G$, and $A C T$ fragments comprised 23 and 25 cycles (each cycle: $30 \mathrm{~s}$ at $94^{\circ} \mathrm{C}, 20 \mathrm{~s}$ at $52^{\circ} \mathrm{C}$, and $30 \mathrm{~s}$ at $72^{\circ} \mathrm{C}$ ); POD6, 25 and 27 cycles (each cycle: $30 \mathrm{~s}$ at $94^{\circ} \mathrm{C}, 20 \mathrm{~s}$ at $58^{\circ} \mathrm{C}$, and $15 \mathrm{~s}$ at $72^{\circ} \mathrm{C}$ ); and GhLOX1, 25 and 27 cycles (each cycle: $30 \mathrm{~s}$ at $94^{\circ} \mathrm{C}, 20 \mathrm{~s}$ at $58^{\circ} \mathrm{C}$, and $40 \mathrm{~s}$ at $72^{\circ} \mathrm{C}$ ) for root and leaf RNA, respectively. PCR products $w$ ere electrophoresed on agarose gels and band intensities compared within each experiment after ethidium bromide staining.

\section{Colletotrichum sp. resistance cotyledons assay.}

Cultures of a Colletotrichum sp. for inoculation were grown for 7 days on PDA at $27^{\circ} \mathrm{C}$ in the dark. Ten-day-old cotton (cv. Paymaster) cotyledons were detached from the seedlings and placed into sterile petri dishes containing moistened filter paper. Cotyledons were elicited as described above, except that different amounts of elicitors were used: a 5- $\mu$ l droplet of Sm1 $(0.5 \mathrm{nmol})$ or SA $(25 \mathrm{nmol})$. After $24 \mathrm{~h}$ of incubation in the dark at $21^{\circ} \mathrm{C}$, an agar plug $(2 \mathrm{~mm}$ in diameter) of Colletotrichum sp. was placed on the adaxial side of each cotyledon which previously was punctured slightly. Following a 10-dayincubation period in the dark at $25^{\circ} \mathrm{C}$, agar plugs were removed and cotyledons were photographed with a digital camera (Canon Power Shot S50; Tokyo). Percentage of the cotyledon area with water-soaking necrosis was determined using Image J software. Each treatment contained seven repetitions and the experiment was repeated at least twice. Data were analyzed by analysis of variance and Fisher's protected least significant difference test $(P<0.05)$ (Statview v. 5.0.1; SAS Institute, Cary, NC, U.S.A.).

\section{ACKNOWLEDGMENTS}

This work was supported by grants from the United States Department of Agriculture National Research Initiative (2003-35316-13861) and National Science Foundation (IOB0445650) to C. M. Kenerley and a fellowship to S. Djonović from the Storkan-Hanes-McCaslin Foundation. We kindly thank S. Sukno (Texas A\&M University) for supplying an isolate of Colletotrichum; T. Wheeler (Texas Agricultural Experimental Station, Lubbock) for seed of the cotton genotypes; B. Shaw for expert assistance in microscopy; R. Omarov for fruitful discussions; and A. MendozaHerrera, J. Garcia, and A. Wiest for technical assistance.

\section{LITERATURE CITED}

Abraham, K. J., Pierce, M. L., and Essenberg, M. 1999. The phytoalexins desoxyhemigossypol and hemigossypol are elicited by Xanthomonas in Gossypium cotyledons. Phytochemistry 52:829-836.

Ahmad, J. S., and Baker, R. 1987. Rhizosphere competence of Trichoderma harzianum. Phytopathology 77:182-189.

Baek, J. M., and Kenerley, C. M. 1998. The arg2 gene of Trichoderma virens: Cloning and development of a homologous transformation system. Fungal Genet. Biol. 23:34-44.

Baek, J. M., Howell, C. R., and Kenerley, C. M. 1999. The role of an extracellular chitinase from Trichoderma virens Gv29-8 in the biocontrol of Rhizoctonia solani. Curr. Genet. 35:41-50.

Bais, H. P., Park, S. W., Weir, T. L., Callaway, R. M., and Vivanco, J. M. 2004. How plants communicate using the underground information superhighway. Trends Plant Sci. 9:26-32.

Baker, C. J., and Orlandi, E. W. 1995. Active oxygen in plant pathogenesis. Annu. Rev. Phytopathol. 33:299-321.

Bateman, A., Coin, L., Durbin, R., Finn, R. D., Hollich, V., Griffiths-Jones, S., Khanna, A., Marshall, M., Moxon, S., Sonnhammer, E. L. L., Studholme, D. J., Yeats, C., and Eddy, S. R. 2004. The Pfam protein families database. Nucleic Acids Res. 32:D138-D141.

Benitez, T., Rincon, A. M., Limon, M. C., and Codon, A. C. 2004. Biocontrol mechanisms of Trichoderma strains. Int. Microbiol. 7:249-260.

Boddi, S., Comparini, C., Calamassi, R., Pazzagli, L., Cappugi, G., and Scala, A. 2004. Cerato-platanin protein is located in the cell walls of ascospores, conidia and hyphae of Ceratocystis fimbriata f. sp. platani. FEMS (Fed. Eur. Microbiol. Soc.) Microbiol. Lett. 233:341-346.

Bolwell, G. P., and Wojtaszek, P. 1997. Mechanisms for the generation of reactive oxygen species in plant defence-A broad perspective. Physiol. Mol. Plant Pathol. 51:347-366.

Bowler, C., and Fluhr, R. 2000. The role of calcium and activated oxygens as signals for controlling cross-tolerance. Trends Plant Sci. 5:241246.

Bowles, D. J. 1990. Defense-related proteins in higher-plants. Annu. Rev. Biochem. 59:873-907.

Calderon, A. A., Zapata, J. M., Munoz, R., Pedreno, M. A., and Barcelo, A. R. 1993. Resveratrol production as a part of the hypersensitive-like 
response of grapevine cells to an elicitor from Trichoderma-Viride. New Phytol. 124:455-463.

Caruso, C., Chilosi, G., Leonardi, L., Bertini, L., Magro, P., Buonocore, V., and Caporale, C. 2001. A basic peroxidase from wheat kernel with antifungal activity. Phytochemistry 58:743-750.

Chang, P. F. L., Xu, Y., Narasimhan, M. L., Cheah, K. T., Durzo, M. P., Damsz, B., Kononowicz, A. K., Abad, L., Hasegawa, P. M., and Bressan, R. A. 1997. Induction of pathogen resistance and pathogenesis-related genes in tobacco by a heat-stable Trichoderma mycelial extract and plant signal messengers. Physiol. Plant 100:341-352.

Chen, X. Y., Chen, Y., Heinstein, P., and Davisson, V. J. 1995. Cloning, expression, and characterization of (+)-delta-cadinene synthase: A catalyst for cotton phytoalexin biosynthesis. Arch. Biochem. Biophys. 324:255266

Chen, X. Y., Wang, M., Chen, Y., Davisson, V. J., and Heinstein, P. 1996 Cloning and heterologous expression of a second (+)-delta-cadinene synthase from Gossypium arboreum. J. Nat. Prod. 59:944-951.

Chet, I., and Chernin, L. 2002. Biocontrol, microbial agents in soil. Pages 450-465 in: Encyclopedia of Environmental Microbiology. G. Bitton, ed. John Wiley \& Sons, New York.

Cortes, C., Gutierrez, A., Olmedo, V., Inbar, J., Chet, I., and HerreraEstrella, A. 1998. The expression of genes involved in parasitism by Trichoderma harzianum is triggered by a diffusible factor. Mol. Gen. Genet. 260:218-225.

Delannoy, E., Jalloul, A., Assigbetse, K., Marmey, P., Geiger, J. P., Lherminier, J., Daniel, J. F., Martinez, C., and Nicole, M. 2003. Activity of class III peroxidases in the defense of cotton to bacterial blight. Mol. Plant-Microbe Interact. 16:1030-1038.

Dixon, R. A., Harrison, M. J., and Lamb, C. J. 1994. Early events in the activation of plant defense responses. Annu. Rev. Phytopathol. 32:479501

Dowd, C., Wilson, L. W., and McFadden, H. 2004. Gene expression profile changes in cotton root and hypocotyl tissues in response to infection with Fusarium oxysporum f. sp. vasinfectum. Mol. Plant-Microbe Interact. 17:654-667.

Duplessis, S., Courty, P. E., Tagu, D., and Martin, F. 2005. Transcript patterns associated with ectomycorrhiza development in Eucalyptus globulus and Pisolithus microcarpus. New Phytol. 165:599-611.

Feussner, I., and Wasternack, C. 2002. The lipoxygenase pathway. Annu. Rev. Plant Biol. 53:275-297.

Fitzgerald, H. A., Chern, M. S., Navarre, R., and Ronald, P. C. 2004. Overexpression of $(A t) N P R 1$ in rice leads to a BTH- and environmentinduced lesion-mimic/cell death phenotype. Mol. Plant-Microbe Interact. 17:140-151.

Flores, A., Chet, I., and Herrera-Estrella, A. 1997. Improved biocontrol activity of Trichoderma harzianum by over-expression of the proteinaseencoding gene prb1. Curr. Genet. 31:30-37.

Fravel, D. R. 2005. Commercialization and implementation of biocontrol (1). Annu. Rev. Phytopathol. 43:337-359.

Friedrich, L., Lawton, K., Ruess, W., Masner, P., Specker, N., Rella, M. G., Meier, B., Dincher, S., Staub, T., Uknes, S., Metraux, J. P., Kessmann, H., and Ryals, J. 1996. A benzothiadiazole derivative induces systemic acquired resistance in tobacco. Plant J. 10:61-70.

Geremia, R. A., Goldman, G. H., Jacobs, D., Ardiles, W., Vila, S. B., Vanmontagu, M., and Herrera-Estrella, A. 1993. Molecular characterization of the proteinase-encoding gene, $p r b 1$, related to mycoparasitism by Trichoderma harzianum. Mol. Microbiol. 8:603-613.

Glazener, J. A., Orlandi, E. W., and Baker, C. J. 1996. The active oxygen response of cell suspensions to incompatible bacteria is not sufficient to cause hypersensitive cell death. Plant Physiol. 110:759-763.

Grzegorski, D. 2001. The construction and characterization of three genomic libraries of Trichoderma virens strain Tv29-8. M.Sc. thesis, Texas A\&M University, College Station, TX, U.S.A.

Hagborg, W. A. F. 1970. A device for injecting solution and suspensions into thin leaves of plants. Can. J. Bot. 48:1135-1136.

Hall, N., Keon, J. P. R., and Hargreaves, J. A. 1999. A homologue of a gene implicated in the virulence of human fungal diseases is present in a plant fungal pathogen and is expressed during infection. Physiol. Mol. Plant Pathol. 55:69-73.

Hammond-Kosack, K. E., and Jones, J. D. G. 1996. Resistance gene-dependent plant defense responses. Plant Cell 8:1773-1791.

Hanson, L. E., and Howell, C. R. 2004. Elicitors of plant defense responses from biocontrol strains of Trichoderma virens. Phytopathology 94:171176

Harman, G. E., Howell, C. R., Viterbo, A., Chet, I., and Lorito, M. 2004a. Trichoderma species-opportunistic, avirulent plant symbionts. Nat. Rev. Microbiol. 2:43-56.

Harman, G. E., Petzoldt, R., Comis, A., and Chen, J. 2004b. Interactions between Trichoderma harzianum strain T22 and maize inbred line Mo17 and effects of these interactions on diseases caused by Pythium ultimum and Colletotrichum graminicola. Phytopathology 94:147-153.

Harrison, M. J. 2005. Signaling in the arbuscular mycorrhizal symbiosis. Annu. Rev. Microbiol. 59:19-42.

Heath, M. C. 2000. Hypersensitive response-related death. Plant Mol. Biol. 44:321-334.

Hemmann, S., Blaser, K., and Crameri, R. 1997. Allergens of Aspergillus fumigatus and Candida boidinii share IgE-binding epitopes. Am. J. Respir. Crit. Care Med. 156:1956-1962.

Hjeljord, L. G., Stensvand, A., and Tronsmo, A. 2000. Effect of temperature and nutrient stress on the capacity of commercial Trichoderma products to control Botrytis cinerea and Mucor piriformis in greenhouse strawberries. Biol. Control 19:149-160.

Honegger, R. 1991. Functional-aspects of the lichen symbiosis. Annu. Rev. Plant Physiol. Plant Mol. Biol. 42:553-578.

Howell, C. R. 2003. Mechanisms employed by Trichoderma species in the biological control of plant diseases: The history and evolution of current concepts. Plant Dis. 87:4-10.

Howell, C. R., Stipanovic, R. D., and Lumsden, R. D. 1993. Antibiotic production by strains of Gliocladium virens and its relation to the biocontrol of cotton seedling diseases. Biocontrol Sci. Technol. 3:435-441.

Howell, C. R., Hanson, L. E., Stipanovic, R. D., and Puckhaber, L. S. 2000. Induction of terpenoid synthesis in cotton roots and control of Rhizoctonia solani by seed treatment with Trichoderma virens. Phytopathology 90:248-252.

Hsu, Y. L., Kuo, Y. C., Kuo, P. L., Ng, L. T., Kuo, Y. H., and Lin, C. C. 2005. Apoptotic effects of extract from Antrodia camphorata fruiting bodies in human hepatocellular carcinoma cell lines. Cancer Lett. 221:77-89.

Huet, J. C., Lecaer, J. P., Nespoulous, C., and Pernollet, J. C. 1995. The Relationships between the toxicity and the primary and secondary structures of elicitinlike protein elicitors secreted by the phytopathogenic fungus Pythium vexans. Mol. Plant-Microbe Interact. 8:302-310.

Hutcheson, S. W. 1998. Current concepts of active defense in plants. Annu. Rev. Phytopathol. 36:59-90.

Jalloul, A., Montillet, J. L., Assigbetse, K., Agnel, J. P., Delannoy, E., Triantaphylides, C., Daniel, J. F., Marmey, P., Geiger, J. P., and Nicole, M. 2002. Lipid peroxidation in cotton: Xanthomonas interactions and the role of lipoxygenases during the hypersensitive reaction. Plant J. 32:1-12.

Jones, J. D. G., Dunsmuir, P., and Bedbrook, J. 1985. High-level expression of introduced chimaeric genes in regenerated transformed plants. EMBO (Eur. Mol. Biol. Organ.) J. 4:2411-2418.

Kim, D. J., Baek, J. M., Uribe, P., Kenerley, C. M., and Cook, D. R. 2002. Cloning and characterization of multiple glycosyl hydrolase genes from Trichoderma virens. Curr. Genet. 40:374-384.

Kulmburg, P., Mathieu, M., Dowzer, C., Kelly, J., and Felenbok, B. 1993. Specific binding-sites in the alcR and alcA promoters of the ethanol regulon for the CREA repressor mediating carbon catabolite repression in Aspergillus nidulans. Mol. Microbiol. 7:847-857.

Limpens, E., and Bisseling, T. 2003. Signaling in symbiosis. Curr. Opin. Plant Biol. 6:343-350.

Madi, L., and Katan, J. 1998. Penicillium janczewskii and its metabolites, applied to leaves, elicit systemic acquired resistance to stem rot caused by Rhizoctonia solani. Physiol. Mol. Plant Pathol. 53:163-175.

Marchler, G., Schuller, C., Adam, G., and Ruis, H. 1993. A Saccharomyces cerevisiae UAS element controlled by protein kinase A activates transcription in response to a variety of stress conditions. EMBO (Eur. Mol. Biol. Organ.) J. 12:1997-2003.

Marchler-Bauer, A., and Bryant, S. H. 2004. CD-Search: Protein domain annotations on the fly. Nucleic Acids Res. 32:W327-W331.

Marck, C. 1988. DNA strider - a C program for the fast analysis of DNA and protein sequences on the Apple Macintosh family of computers. Nucleic Acids Res. 16:1829-1836.

Martinez, C., Baccou, J. C., Bresson, E., Baissac, Y., Daniel, J. F., Jalloul, A., Montillet, J. L., Geiger, J. P., Assigbetse, K., and Nicole, M. 2000 Salicylic acid mediated by the oxidative burst is a key molecule in local and systemic responses of cotton challenged by an avirulent race of Xanthomonas campestris pv. malvacearum. Plant Physiol. 122:757-766.

Martinez, C., Blanc, F., LeClaire, E., Besnard, O., Nicole, M., and Baccou, J. C. 2001. Salicylic acid and ethylene pathways are differentially activated in melon cotyledons by active or heat-denatured cellulase from Trichoderma longibrachiatum. Plant Physiol. 127:334-344.

McLeod, A., Smart, C. D., and Fry, W. E. 2003. Characterization of 1,3beta-glucanase and 1,3;1,4-beta-glucanase genes from Phytophthora infestans. Fungal Genet. Biol. 38:250-263.

Mendoza-Mendoza, A., Pozo, M. J., Grzegorski, D., Martinez, P., Garcia, J. M., Olmedo-Monfil, V., Cortes, C., Kenerley, C., and HerreraEstrella, A. 2003. Enhanced biocontrol activity of Trichoderma through inactivation of a mitogen-activated protein kinase. Proc. Natl. Acad. Sci. U.S.A. 100:15965-15970. 
Mittler, R., Vanderauwera, S., Gollery, M., and Van Breusegem, F. 2004 Reactive oxygen gene network of plants. Trends Plant Sci. 9:490-498.

Nelson, N. J. 1957. Colorimetric analysis of sugars. Methods Enzymol. 3:85-86.

Nicholson, R. L., and Hammerschmidt, R. 1992. Phenolic compounds and their role in disease resistance. Annu. Rev. Phytopathol. 30:369-389.

Nimchuk, Z., Eulgem, T., Holt, B. F., 3rd, and Dangl, J. L. 2003. Recognition and response in the plant immune system. Annu. Rev. Genet. 37:579-609.

Olmedo-Monfil, V., Mendoza-Mendoza, A., Gomez, I., Cortes, C., and Herrera-Estrella, A. 2002. Multiple environmental signals determine the transcriptional activation of the mycoparasitism related gene prb1 in Trichoderma atroviride. Mol. Genet. Genomics 267:703-712.

Pace, C. N., Vajdos, F., Fee, L., Grimsley, G., and Gray, T. 1995. How to measure and predict the molar absorption coefficient of a protein. Protein Sci. 4:2411-2423.

Pan, S. C., and Cole, G. T. 1995. Molecular and biochemical characterization of a Coccidioides Immitis-specific antigen. Infect. Immun 63:3994-4002.

Park, Y. H., Kenerley, C. M., and Stack, J. P. 1992. Inoculum dynamics of Gliocladium virens associated with roots of cotton seedlings. Microb. Ecol. 23:169-179.

Pazzagli, L., Cappugi, G., Manao, G., Camici, G., Santini, A., and Scala, A. 1999. Purification, characterization, and amino acid sequence of cerato-platanin, a new phytotoxic protein from Ceratocystis fimbriata $\mathrm{f}$. sp. platani. J. Biol. Chem. 274:24959-24964.

Peter, M., Courty, P. E., Kohler, A., Delaruelle, C., Martin, D., Tagu, D., Frey-Klett, P., Duplessis, S., Chalot, M., Podila, G., and Martin, F. 2003. Analysis of expressed sequence tags from the ectomycorrhizal basidiomycetes Laccaria bicolor and Pisolithus microcarpus. New Phytol. 159:117-129.

Pieterse, C. M. J., Van Pelt, J. A., Verhagen, B. W. M., Ton, J., Van Wees, S. C. M., Leon-Kloosterziel, K. M., and Van Loon, L. C. 2003. Induced systemic resistance by plant growth-promoting rhizobacteria. Symbiosis 35:39-54.

Pieterse, C. M. J., Van Wees, S. C. M., Van Pelt, J. A., Knoester, M., Laan, R., Gerrits, N., Weisbeek, P. J., and Van Loon, L. C. 1998. A novel signaling pathway controlling induced systemic resistance in Arabidopsis. Plant Cell 10:1571-1580.

Pozo, M. J., Baek, J. M., Garcia, J. M., and Kenerley, C. M. 2004. Functional analysis of tvspl, a serine protease-encoding gene in the biocontrol agent Trichoderma virens. Fungal Genet. Biol. 41:336-348.

Pozo, M. J., Van Loon, L. C., and Pieterse, C. M. J. 2005. Jasmonates-Signals in plant-microbe interactions. J. Plant Growth Regul. 23:211-222.

Prusky, D., Freeman, S., and Dickman, M. B. 2000. Colletotrichum: Host Specificity, Pathology and Host Pathogen Interaction of Colletotrichum. American Phytopathological Society, St. Paul, MN, U.S.A.

Quiroga, M., Guerrero, C., Botella, M. A., Barcelo, A., Amaya, I., Medina, M. I., Alonso, F. J., De Forchetti, S. M., Tigier, H., and Valpuesta, V. 2000. A tomato peroxidase involved in the synthesis of lignin and suberin. Plant Physiol. 122:1119-1127.

Rance, I. I., Fournier, J., and Esquerre-Tugaye, M. T. 1998. The incompatible interaction between Phytophthora parasitica var. nicotianae race 0 and tobacco is suppressed in transgenic plants expressing antisense lipoxygenase sequences. Proc. Natl. Acad. Sci. U.S.A. 95:6554-6559.

Ravagnani, A., Gorfinkiel, L., Langdon, T., Diallinas, G., Adjadj, E., Demais, S., Gorton, D., Arst, H. N., and Scazzocchio, C. 1997. Subtle hydrophobic interactions between the seventh residue of the zinc finger loop and the first base of an HGATAR sequence determine promoterspecific recognition by the Aspergillus nidulans GATA factor AreA EMBO (Eur. Mol. Biol. Organ.) J. 16:3974-3986.

Ren, Y. Y., and West, C. A. 1992. Elicitation of diterpene biosynthesis in rice (Oryza-Sativa L) by Chitin. Plant Physiol. 99:1169-1178.

Ron, M., Kantety, R., Martin, G. B., Avidan, N., Eshed, Y., Zamir, D., and Avni, A. 2000. High-resolution linkage analysis and physical characterization of the EIX-responding locus in tomato. Theor. Appl. Genet. 100:184-189.

Sambrook, J., Fritsch, E. F., and Maniatis, T. 1989. Molecular Cloning: A Laboratory Manual. Cold Spring Harbor Laboratory Press, Cold Spring Harbor, NY, U.S.A.

Sasaki, K., Iwai, T., Hiraga, S., Kuroda, K., Seo, S., Mitsuhara, I., Miyasaka, A., Iwano, M., Ito, H., Matsui, H., and Ohashi, Y. 2004. Ten rice peroxidases redundantly respond to multiple stresses including infection with rice blast fungus. Plant Cell Physiol. 45:1442-1452.

Scala, A., Pazzagli, L., Comparini, C., Santini, A., Tegli, S., and Cappugi, G. 2004. Cerato-platanin, an early-produced protein by Ceratocystis fimbriata f. sp. platani, elicits phytoalexin synthesis in host and nonhost plants. J. Plant Pathol. 86:27-33.

Scherrer, S., De Vries, O. M. H., Dudler, R., Wessels, J. G. H., and Honegger, R. 2000. Interfacial self-assembly of fungal hydrophobins of the lichen-forming ascomycetes Xanthoria parietina and X. ectaneoides. Fungal Genet. Biol. 30:81-93.

Shoresh, M., Yedidia, I., and Chet, I. 2005. Involvement of jasmonic acid/ethylene signaling pathway in the systemic resistance induced in cucumber by Trichoderma asperellum T-203. Phytopathology 95:76-84.

Sivasithamparam, K., and Ghisalberti, E. L. 1998. Secondary metabolism in Trichoderma and Gliocladium. Pages 139-191 in: Trichoderma and Gliocladium. C. P. Kubicek and G. E. Harman, eds. Taylor \& Francis Inc., Bristol, PA, U.S.A.

Somssich, I. E., and Hahlbrock, K. 1998. Pathogen defence in plants-A paradigm of biological complexity. Trends Plant Sci. 3:86-90.

Sophianopoulou, V., Suarez, T., Diallinas, G., and Scazzocchio, C. 1993. Operator derepressed mutations in the proline utilization gene-cluster of Aspergillus-nidulans. Mol. Gen. Genet. 236:209-213.

Stipanovic, R. D., Bell, A. A., and Benedict, C. R. 1999. Cotton pest resistance: The role of pigmented gland constituents. Pages 211-220 in: Biologically Active Natural Products: Agrochemicals. H. G. Cutler and S. Cutler, eds. CRC Press, Boca Raton, FL, U.S.A.

Tagu, D., Nasse, B., and Martin, F. 1996. Cloning and characterization of hydrophobins-encoding cDNAs from the ectomycorrhizal basidiomycete Pisolithus tinctorius. Gene 168:93-97.

Tagu, D., Lapeyrie, F., and Martin, F. 2002. The ectomycorrhizal symbiosis: Genetics and development. Plant Soil 244:97-105.

Tan, X. P., Liang, W. Q., Liu, C. J., Luo, P., Heinstein, P., and Chen, X. Y. 2000. Expression pattern of (+)-delta-cadinene synthase genes and biosynthesis of sesquiterpene aldehydes in plants of Gossypium arboretum. L. Planta 210:644-651.

Templeton, M. D., Rikkerink, E. H. A., and Beever, R. E. 1994. Small, cysteine-rich proteins and recognition in fungal-plant interactions. Mol. Plant-Microbe Interact. 7:320-325.

Thomas, M. D., and Kenerley, C. M. 1989. Transformation of the mycoparasite Gliocladium. Curr. Genet. 15:415-420.

Tilburn, J., Sarkar, S., Widdick, D. A., Espeso, E. A., Orejas, M., Mungroo, J., Penalva, M. A., and Arst, H. N. 1995. The Aspergillus PacC zincfinger transcription factor mediates regulation of both acid-expressed and alkaline-expressed genes by ambient pH. EMBO (Eur. Mol. Biol. Organ.) J. 14:779-790.

Tucker, S. L., and Talbot, N. J. 2001. Surface attachment and pre-penetration stage development by plant pathogenic fungi. Annu. Rev. Phytopathol. 39:385-417.

Van Loon, L. C., and Van Strien, E. A. 1999. The families of pathogenesisrelated proteins, their activities, and comparative analysis of PR-1 type proteins. Physiol. Mol. Plant Pathol. 55:85-97.

Van West, P., De Jong, A. J., Judelson, H. S., Emons, A. M. C., and Govers, F. 1998. The ipiO gene of Phytophthora infestans is highly expressed in invading hyphae during infection. Fungal Genet. Biol. 23:126-138.

Viterbo, A., Harel, M., and Chet, I. 2004. Isolation of two aspartyl proteases from Trichoderma asperellum expressed during colonization of cucumber roots. FEMS (Fed. Eur. Microbiol. Soc.) Microbiol. Lett. 238:151-158.

Vogel, H. J. 1956. A convenient growth medium for Neurospora (Medium N). Microbiol. Genet. Bull. 13:42-43.

Wang, S. X., Hunter, W., and Plant, A. 2000. Isolation and purification of functional total RNA from woody branches and needles of Sitka and white spruce. BioTechniques 28:292-297.

Ward, E. R., Uknes, S. J., Williams, S. C., Dincher, S. S., Wiederhold, D. L., Alexander, D. C., Ahlgoy, P., Metraux, J. P., and Ryals, J. A. 1991. Coordinate gene activity in response to agents that induce systemic acquired-resistance. Plant Cell 3:1085-1094.

Wiest, A., Grzegorski, D., Xu, B. W., Goulard, C., Rebuffat, S., Ebbole, D. J., Bodo, B., and Kenerley, C. 2002. Identification of peptaibols from Trichoderma virens and cloning of a peptaibol synthetase. J. Biol. Chem. 277:20862-20868.

Wilson, L. M., Idnurm, A., and Howlett, B. J. 2002. Characterization of a gene (spl) encoding a secreted protein from Leptosphaeria maculans, the blackleg pathogen of Brassica napus. Mol. Plant Pathol. 3:487-493.

Wilson, R. A., Gardner, H. W., and Keller, N. P. 2001. Cultivar-dependent expression of a maize lipoxygenase responsive to seed infesting fungi. Mol. Plant-Microbe Interact. 14:980-987.

Wosten, H. A. B. 2001. Hydrophobins: Multipurpose proteins. Annu. Rev. Microbiol. 55:625-646.

Xu, B. W., Wild, J. R., and Kenerley, C. M. 1996. Enhanced expression of a bacterial gene for pesticide degradation in a common soil fungus. $\mathrm{J}$. Ferment. Bioeng. 81:473-481.

Yang, Y. O., Shah, J., and Klessig, D. F. 1997. Signal perception and transduction in defense responses. Genes Dev. 11:1621-1639.

Yedidia, I., Benhamou, N., and Chet, I. 1999. Induction of defense responses in cucumber plants (Cucumis sativus L.) by the biocontrol agent Trichoderma harzianum. Appl. Environ. Microbiol. 65:1061-1070.

Yedidia, I., Benhamou, N., Kapulnik, Y., and Chet, I. 2000. Induction and 
accumulation of PR proteins activity during early stages of root colonization by the mycoparasite Trichoderma harzianum strain T-203. Plant Physiol. Biochem. 38:863-873.

Yedidia, I., Shoresh, M., Kerem, Z., Benhamou, N., Kapulnik, Y., and Chet, I. 2003. Concomitant induction of systemic resistance to Pseudomonas spingae pv. lachrymans in cucumber by Trichoderma asperellum (T-203) and accumulation of phytoalexins. Appl. Environ. Microbiol. 69:73437353.

Zeilinger, S., Reithner, B., Scala, V., Peissl, I., Lorito, M., and Mach, R. L. 2005. Signal transduction by Tga3, a novel g protein subunit alpha of Trichoderma atroviride. Appl. Environ. Microbiol. 71:1591-1597.
AUTHOR-RECOMMENDED INTERNET RESOURCES

European Bioinformatics Institute EMBL-EBI database: www.ebi.ac.uk/MPsrch

Trichoderma reesei EST Database and Mitochondrial Genome: trichoderma.iq.usp.br

Swiss Institute of Bioinformatics ExPASy (Expert Protein Analysis System) proteomics server: us.expasy.org

EMBOSS at European Bioinformatics Institute: www.ebi.ac.uk/emboss ClustalW at Kyoto University Bioinformatics Center: clustalw.genome.jp Image J software: rsb.info.nih.gov/ij 